\title{
PLANEJAMENTO ECONÔMICO E CRISE POLÍTICA: DO ESGOTAMENTO DO PLANO DE DESENVOLVIMENTO AO MALOGRO DOS PROGRAMAS DE ESTABILIZAÇÃO
}

\author{
Ricardo Silva \\ Universidade Federal de Santa Catarina
}

\begin{abstract}
RESUMO
Este artigo tem como objetivo reconstruir a trajetória dos programas de estabilização da economia elaborados no contexto da crise do início dos anos sessenta no Brasil. Na conjuntura compreendida entre o final dos anos cinqüenta e a queda do governo João Goulart (abril de 1964), ao menos três programas mais ambiciosos de estabilização monetária foram tentados pelos governos do periodo, todos sem êxito. Iremos nos ater nas reações políticas dos diferentes atores, naquela conjuntura crítica, em relação ao Plano de Estabilização Monetária (1958-1959) do governo Kubitschek, à Reforma Cambial (1961) do governo Quadros e, com mais detalhe, ao Plano Trienal (1963-1965) do governo Goulart. Ver-se-á que tais reações decorrem da dissolução do consenso ideológico em torno das politicas desenvolvimentistas e da negativa dos principais grupos sócio-econômicos à submissão aos "sacrificios" impostos pelos planejadores para a consecução da estabilidade monetária.
\end{abstract}

PALAVRAS-CHAVE: planejamento econômico; políticas de estabilização; crise política; crise institucional; desenvolvimento; estabilidade; anos sessenta.

\section{INTRODUÇÃO}

No final dos anos cinqüenta, quando o Brasil ainda experimentava um intenso processo de crescimento industrial embalado pelos projetos governamentais da década, a política econômica oficial passou a apresentar uma importante inflexão. Os problemas relacionados à estabilidade monetária interna e ao desequilíbrio das contas externas passam a assumir a primazia nas preocupações dos planejadores e gestores da política econômica, em substituição à orientação desenvolvimentista e industrializante predominante até então.

Tal inflexão evidenciou-se nas sucessivas tentativas de planejamento econômico realizadas entre o final dos anos cinqüenta e o golpe de março de 1964. A aceleração do processo inflacionário combinada com a deterioração das contas externas transformou-se no principal problema colocado não somente para os planejadores como também para as mais influentes vozes no debate técnicoeconômico. A questão já não era tanto como incrementar o crescimento econômico e a industrialização, mas de que modo assegurar o controle da inflação e o equilíbrio das contas externas. O fenômeno da inflação deixou de ser considerado como um mero subproduto (ainda que não desejável) da industrialização brasileira, autonomizando-se como problema teórico e prático e assumindo prioridade nos debates dos círculos dominantes.

A reorientação da política econômica, de uma estratégia desenvolvimentista para uma estratégia de estabilização, resultou principalmente no surgimento de um novo quadro de reações políticas às tentativas de implementação dos planos econômicos do período. Como é óbvio, políticas de desenvolvimento tendem a enfrentar reações menos vigorosas e a contar com apoios mais consistentes do que políticas de estabilização. A distribuição desigual de novos recursos gerados tende a ser menos conflituosa do que a distribuição de "sacrifícios".

Este artigo pretende reconstruir a trajetória dos programas de estabilização econômica formulados na esteira da crise do "desenvolvimentismo", dando ênfase à dimensão propriamente política do processo de elaboração e sobretudo de implementação de tais programas. Tentaremos observar o comportamento de diversos atores relevantes tais 
como técnicos, políticos, empresários e trabalhadores em relação às diferentes medidas contidas nos principais programas de estabilização do período. Vale lembrar que tais programas vieram à luz em um momento bastante especial da história política brasileira, que combinou, como nenhum outro, uma forte mobilização política e social com uma profunda crise institucional, agravado ainda pela intensa radicalização e polarização ideológica. Momento que se encerrou tragicamente em 1964 pela via da desmobilização com repressão.

Inicialmente, observaremos as condições que permitiram o impressionante êxito da política desenvolvimentista de Juscelino Kubitschek consubstanciada no célebre Plano de Metas. Daremos destaque às condições de administração e financiamento do Plano, chamando a atenção para os principais problemas econômicos derivados da experiência da "euforia desenvolvimentista". Esses problemas iriam balizar as tentativas de planejamento econômico subseqüentes. Em seguida, em grau crescente de detalhamento, analisaremos a recepção política dos programas de estabilização mais relevantes do período. Após uma breve análise do Plano de Estabilização Monetária (1958-1959) do Governo Kubitschek e da Reforma Cambial (1961) do Governo Quadros, aprofundaremos a análise da experiência do Plano Trienal do Governo Goulart, o qual representou a última tentativa de planejamento econômico nos marcos do regime político da Constituição de 1946.

\section{O PLANO DE METAS (1957-1961) E AS BASES FRÁGEIS DO DESENVOLVIMEN- TO}

Durante a segunda metade dos anos cinqüenta, a economia brasileira experimentou um crescimento bastante intenso, com especial destaque para o setor industrial. De 1957 a 1961, o Produto Real expandiu-se à taxa média anual de 8,3\%, sendo que, enquanto o setor agrícola cresceu, neste mesmo período, $5,8 \%$ em média por ano, a indústria registrou um crescimento médio anual de $10,8 \%$, chegando a atingir, em 1958, a impressionante taxa de $16,2 \%$ de crescimento real contra apenas $2,1 \%$ de crescimento agrícola.

Esses números significaram sem dúvida uma profunda mudança no estilo de desenvolvimento da economia brasileira, que até o ano de 1955 apresentava o valor total da produção agrícola acima do valor da produção industrial e que, ainda em 1950 , contava com $57,8 \%$ da população (acima de 10 anos) empregada na agricultura.

Viveu-se nesses anos - que coincidiram em boa parte com o período de Governo de Juscelino Kubitschek - o momento de auge do desenvolvimentismo, ideologia que nucleou o debate técnico e político entre as elites autodeclaradas comprometidas com a "construção da nação". O desenvolvimentismo forneceu a base (sobretudo durante Kubitschek) para a organização do discurso e, em boa medida, das práticas das autoridades governamentais.

Em sua forma mais pura, o desenvolvimentismo pode ser concebido como uma ideologia cuja proposição política básica é a industrialização capitalista planejada e coordenada pelo Estado. Mesmo atribuindo ao planejamento estatal uma função apenas indicativa, cabendo portanto à iniciativa privada as decisões finais de investimento, é inquestionável o papel-chave assumido pelo Estado nesse sistema ideológico. Isso decorre principalmente da constatação de que a livre movimentação dos mecanismos de mercado não possuía a virtuosidade de desencadear um processo vigoroso de industrialização, ainda mais nos países pertencentes à periferia do capitalismo mundial. Ao Estado (ou, mais precisamente, às suas elites) caberia a tarefa de encontrar e seguir o caminho da industrialização. Para isso, seriam indispensáveis as técnicas e conhecimentos produzidos pela ciência econômica, o principal manancial de idéias para os planos de desenvolvimento.

Estamos assim diante de três pressupostos básicos que constituem os alicerces da ideologia desenvolvimentista. Primeiro, o pressuposto de que a industrialização, per se, levaria o país a um estágio de desenvolvimento no qual seriam superados os problemas de desigualdades tanto sociais quanto regionais. Segundo, o pressuposto de que a ação estatal far-se-ia pautada em critérios de racionalidade técnica, concebendo, portanto, o Estado com um considerável (talvez excessivo) grau de autonomia em relação aos interesses e valores dos diferentes grupos e classes sociais. Por último, o pressuposto de que através das técnicas e conhecimentos produzidos pela ciência econômica chegarse-ia ao reconhecimento das necessidades do desenvolvimento e dos meios pelos quais o atingir ${ }^{1}$.

\footnotetext{
1 Até o início dos anos sessenta, esses três pressupostos permaneceram praticamente sem questionamento, o que
} 
Os anos do Governo Kubitschek refletiram o momento no qual mais intensamente se manifestou a crença na efetividade desses pressupostos. Tivemos o Plano, o Estado ativo e empreendedor e o saber dos economistas influenciando os rumos da ação estatal. E tudo isso aparece cristalizado na forma de um documento que viria a ser o programa oficial de Governo de Kubitschek, o conhecido Plano de Metas.

Formulado por uma equipe chefiada pelo engenheiro Lucas Lopes, que viria a tornar-se em 1958 Ministro da Fazenda, e pelo economista Roberto Campos, superintendente do BNDE, o Plano partia de uma série de análises sobre a economia brasileira formuladas no âmbito de missões técnicas, dentre as quais se destaca a Comissão Mista Brasil-Estados Unidos, realizada entre 1951 e 1953. O diagnóstico do Plano de Metas partia da idéia de que havia no sistema econômico brasileiro determinados "pontos de estrangulamento", que configuravam a existência de certas áreas de demanda insatisfeitas e inibidoras do crescimento econômico. Os setores de energia, transportes e alimentação eram considerados os principais pontos de estrangulamento na economia brasileira a requererem maciços investimentos.

A programação prevista no Plano de Metas seguia um planejamento de tipo setorial. Essa característica o distinguia de propostas de planejamento mais globalizantes, como aquelas advogadas pela $\mathrm{CEPAL}^{2}$. Na verdade, apenas algo em

reflete a intensa hegemonia da ideologia desenvolvimentista até então. Para maiores detalhes das diversas fases de evolução da ideologia desenvolvimentista, consultar BIELSCHOWSKY (1988). Este autor percebe três momentos na evolução da ideologia desenvolvimentista: de 1930 a 1944, a origem do desenvolvimentismo; de 1945 a 1955, o período de amadurecimento da ideologia; de 1956 a 1964, o auge e a crise do desenvolvimentismo.

2 Isso, entretanto, não significa que o Plano não teve influência de conceitos e técnicas elaborados no âmbito dessa instituição. Basta mencionar a importância dos escritórios BNDE-CEPAL, na formação de quadros para o setor público, cuja atribuição precípua era a formulação e gestão do processo de planejamento. Ademais, não é desconhecida a influência desses escritórios na elaboração do próprio Plano de Metas, que tinha como um de seus principais mentores Roberto Campos, presidente do BNDE e um dos diretores do programa conjunto com a CEPAL. torno da quarta parte da economia estava sujeita à ação do Plano, o que facilitava a tarefa política de sua implementação, já que o restante do sistema econômico poderia acomodar-se segundo os meios tradicionais de alocação de recursos (LAFER, 1975 , p. 36).

O Plano atuava basicamente em cinco setores: energia, transportes, alimentação, indústrias de base e educação. Entretanto, foram os setores de energia, transportes e indústrias de base que receberam maior atenção dos planejadores. Nada menos que $93,4 \%$ dos investimentos inicialmente previstos destinavam-se a esses setores. Para o setor de energia, o Plano previa 43,4\% do investimento total; os de transportes e indústrias de base recebiam $29,6 \%$ e $20,4 \%$, respectivamente. Cada um dos setores contemplados pelo Plano decompunha-se numa série determinada de metas específicas, num total de trinta metas, assim distribuídas: setor energia - energia elétrica, energia nuclear, carvão mineral, produção de petróleo e refino de petróleo; setor transportes reaparelhamento de ferrovias, construção de ferrovias, pavimentação e construção de rodovias, serviços portuários e de drenagem, marinha mercante e transportes aeroviários; setor alimentação - trigo, armazéns e silos, armazéns frigoríficos, matadouros industriais, mecanização da agricultura e fertilizantes; setor indústrias de base - siderurgia, alumínio, metais não-ferrosos, cimento, álcalis, papel e celulose, borracha, exportação de minérios de ferro, indústria automobilística, indústria de construção naval e indústria mecânica e de material elétrico pesado; setor educação formação de pessoal técnico. Além de todas essas metas, o Plano destacava, como meta-síntese, a construção de Brasília, que mobilizou cerca de 300 bilhões de cruzeiros, em preços de 1961.

Pode-se afirmar, enfaticamente, que a programação prevista no Plano para cada uma dessas metas foi realizada com êxito. Em alguns casos, como o refino e produção de petróleo, por exemplo, a meta inicial foi inclusive revista e fixada num patamar bem mais elevado.

Isso posto, cabe a seguinte pergunta: que fatores permitiram tão surpreendente êxito à implementação do Plano de Metas? É importante, para começarmos a respondê-la, considerarmos dois aspectos essenciais envolvidos na implementação de qualquer plano de desenvolvimento, quais sejam, a administração e o financiamento do plano. 
Com relação ao primeiro aspecto, no que tange ao Plano de Metas, não se pode afirmar que foi requerida qualquer grande reforma administrativa com vistas à sua implementação. Mesmo porque isso certamente provocaria, se tentado, um poderoso foco de reação ao Plano, provindo dos setores clientelistas encastelados na máquina estatal, já que uma reforma nesse sentido implicaria uma racionalização do aparelho estatal contrária às práticas administrativas tradicionais. De resto, não podemos deixar de considerar que essas práticas estavam solidamente arraigadas no sistema político, sendo inclusive, em grande parte, responsáveis pela vitória eleitoral de Kubitschek. Em nenhum outro partido político tais práticas eram tão difundidas quanto no PSD, maior partido do Congresso e no qual militava Kubitschek.

$\mathrm{Na}$ impossibilidade de uma profunda reforma administrativa que deslocasse os interesses clientelistas, optou-se por seguir uma linha de menor resistência. Enquanto se deixava praticamente intacta a estrutura administrativa existente, mobilizava-se, na medida das necessidades, uma espécie de administração paralela, formada pela criação de novos órgãos administrativos, tais como os Grupos de Trabalho e os Grupos Executivos, bem como pela maximização das funções e prerrogativas de órgãos já existentes na estrutura administrativa, porém considerados "ilhas de racionalidade" no conjunto do aparelho estatal, como o BNDE (Banco Nacional de Desenvolvimento Econômico) e a SUMOC (Superintendência da Moeda e do Crédito). Conforme observou Maria Victória Benevides, em seu estudo sobre o Governo Kubitschek, "a administração paralela era um esquema racional dentro da lógica do sistema - evitando o imobilismo do sistema sem ter que contestá-lo radicalmente -, uma vez que os novos órgãos funcionavam como centros de assessoria e de execução, enquanto que os antigos continuavam a corresponder aos interesses da política de clientela ainda vigente" (BENEVIDES, 1976, p. 224-225).

Nas funções de coordenação do Plano de Metas junto ao setor privado, nenhuma instituição desempenhou papel mais relevante que os diversos Grupos Executivos. O caso paradigmático, não só por se tratar do primeiro Grupo Executivo a ser criado, mas também pela importância do setor ao qual se dirigia, foi o GEIA (Grupo Executivo da Indústria Automobilística), cujas atribuições eram as seguintes: “a) elaborar e submeter ao Presidente da República os planos nacionais para a fabricação de diversos tipos de veículos (caminhões, jeeps, furgões e automóveis); b) examinar, negociar e aprovar os projetos de empresas e providenciar, com os organismos competentes da administração, a adoção de medidas comerciais e de câmbio necessárias à sua realização; c) supervisionar a execução dos projetos aprovados; d) recomendar às instituições de crédito a concessão dos financiamentos necessários; e) promover e coordenar as medidas complementares para a implantação da indústria" (MARTINS, 1976, p. 419). O grupo era presidido pelo Ministro dos Transportes e incluía ainda um representante da SUMOC, dois representantes do Banco do Brasil e um do BNDE. Participavam também do GEIA, desempenhando funções apenas consultivas (sem direito a voto), representantes empresariais dos diversos setores da indústria, escolhidos pelo Presidente da República a partir de uma lista tríplice enviada pelas associações de classe.

Se os Grupos Executivos desempenharam um papel fundamental na coordenação do Plano junto ao setor privado, no que diz respeito ao setor público, esse papel de coordenação coube basicamente ao BNDE e à SUMOC. Enquanto o BNDE exercia as funções de outorgar empréstimos estrangeiros, a SUMOC possuía a prerrogativa de abrir acesso aos favores especiais de importação e captação de recursos externos ${ }^{3}$.

Como aponta LAFER (1975, p. 40-41), esses órgãos da administração paralela, incluindo a CACEX e o Conselho de Política Aduaneira, constituíam-se em "órgãos de ponta" da administração federal, possuindo o controle de certas zonas de incerteza geralmente associadas à oferta de tecnologia e de recursos financeiros, o que aumentava consideravelmente os recursos de poder de quem os ocupava.

\footnotetext{
3 A importância do BNDE na implementação do Plano de Metas é assinalada por LESSA (1982, p. 105): "Este banco de investimento, ponto de passagem praticamente obrigatório dos programas governamentais, previa, igualmente, uma melhor compatibilidade dos programas e decisões assumidos setorialmente, ao manipular sua massa de poderes segundo critérios econômicos superiores aos alcançáveis nas unidades isoladas. Preencheu, assim, o BNDE, de forma não declarada, a função de centro de análise de programas governamentais, constituindo-se, por mais esta razão, na peça básica da filosofia do Plano de Metas".
} 
Para melhor avaliar as condições que viabilizaram o êxito do Plano no que se refere à execução de suas metas físicas, e, ao mesmo tempo, para a consideração de algumas de suas conseqüências não desejadas no plano financeiro, é importante considerarmos as principais características da estratégia de financiamento do Plano de Metas.

O primeiro aspecto a ser destacado é a importância do capital estrangeiro. Desde 1953, as autoridades governamentais mudaram sua política em relação ao capital estrangeiro. Isso se deu basicamente devido a uma maior vinculação da regulação das taxas de câmbio em consonância com as necessidades do desenvolvimento econômico, abandonando-se a estratégia de vincular tal regulação à correção do desequilíbrio do balanço de pagamentos, como ocorrera na política cambial de 1947 a 1953.

A Lei ${ }^{\circ} 1807$ - de janeiro de 1953 - criou um mercado livre de câmbio acessível àquelas exportações que o Governo pretendia estimular. Em outubro do mesmo ano, através de Instrução $\mathrm{n}^{\circ} 70$ da SUMOC, foi realizada uma profunda reforma no sistema cambial. Essa Instrução e a Lei $\mathrm{n}^{\circ} 2145$ "estabeleceram o sistema de taxas múltiplas de câmbio, eliminado-se os controles quantitativos diretos e introduzindo-se o sistema de leilões de câmbio. As importações foram classificadas em cinco categorias, dependendo do seu grau de essencialidade e a cada uma delas correspondendo uma taxa de câmbio específica, a ser fixada através de leilões dos certificados emitidos para cada categoria" (BAER, 1985, p. 45). Alguns produtos foram enquadrados na categoria preferencial, podendo sua importação ser feita à taxa de câmbio oficial com o acréscimo de uma sobretaxa determinada pela SUMOC. Era o caso de produtos como o petróleo e seus derivados, papel de imprensa e uma série de equipamentos considerados indispensáveis para a manutenção do processo de industrialização em curso.

Com a Instrução $n^{\circ} 70$, o Banco do Brasil readquiriu o monopólio de compra e venda de moeda estrangeira. Para todos os produtos exportados, o Banco do Brasil pagava a taxa oficial de câmbio com um acréscimo de 10 cruzeiros por dólar, exceto para o café, cujo acréscimo por dólar era de 5 cruzeiros. Particularmente estimulante para o ingresso de capitais estrangeiros era a medida que estabelecia que "a remessa de lucros, juros e amortizações de investimentos estrangeiros considerados essenciais ao desenvolvimento econômico do país, subordinada à Lei $\mathrm{n}^{\circ} 1807$, podia ser convertida à taxa oficial acrescida de uma sobretaxa fixada pela SUMOC" (BAER, 1985, p. 46).

Porém, a medida de maior impacto no que se relaciona aos estímulos concedidos à entrada de capitais estrangeiros foi a Instrução $\mathrm{n}^{\circ} 113 \mathrm{da}$ SUMOC. Baixada durante interregno de Café Filho, por determinação de Eugênio Gudin, à época Ministro da Fazenda, essa medida possibilitava aos investidores estrangeiros a importação de bens de capital sem a necessidade de cobertura cambial. Desse privilégio não participavam os investidores nacionais. A medida foi mantida e largamente utilizada na administração do Plano de Metas. Os projetos eram examinados e aprovados pela CACEX que, além disso, possuía a faculdade de conceder câmbio de custo para a remessa de rendimentos e amortizações das inversões diretas do exterior, até o limite de $10 \%$ do capital registrado da empresa, aos empreendimentos julgados de interesse para o desenvolvimento da economia nacional.

Complementando esses instrumentos legais estimulantes para o ingresso de capitais estrangeiros, verificou-se a importante atuação do BNDE como avalista, junto às instituições financeiras internacionais, para os empresários dispostos a seguir as diretrizes do Plano.

Para se ter uma idéia do que representaram os recursos estrangeiros para o financiamento do Plano de Metas, basta lembrar que, em 1955, aqueles setores contemplados no Plano receberam financiamentos externos num total de 79,4 milhões de dólares. Esses recursos alcançaram 253,4 milhões, em 1956; 234,7 milhões, em 1957; 392,4 milhões, em 1958; 354,7 milhões, em 1959; 242,1 milhões, em 1960. Os investimentos diretos licenciados pela CACEX tiveram a seguinte evolução: 31,3 milhões de dólares, em 1955; 57,7 milhões, em 1956; 108,2 milhões, em 1957; 82,5 milhões, em 1958; 65,8 milhões, em 1959; e 106,8 milhões, em 1960 (cf. LESSA, 1982). Cabe notar que esses financiamentos e investimentos diretos eram predominantemente norte-americanos, seguidos dos capitais da Alemanha Ocidental, França e Inglaterra. Somente em 1958, ano de maior dinamismo no Plano de Metas, os capitais norte-americanos para financiamento atingiram a quantia de 285,9 milhões de dólares, enquanto os investimentos 
diretos foram de 55,4 milhões.

Além dos recursos externos, outra importante fonte de financiamento para o Plano de Metas encontrava-se no setor público. O quadro abaixo mostra a evolução da participação do setor público no dispêndio total.

Tabela 1. Participação percentual do setor público no dispêndio total

\begin{tabular}{lcccccccc}
\hline DISCRIMINAÇÃO & $\mathbf{1 9 4 7}$ & $\mathbf{1 9 5 0}$ & $\mathbf{1 9 5 5}$ & $\mathbf{1 9 5 6}$ & $\mathbf{1 9 5 7}$ & $\mathbf{1 9 5 8}$ & $\mathbf{1 9 5 9}$ & $\mathbf{1 9 6 0}$ \\
\hline Consumo Público & 10,7 & 12,7 & 13,6 & 14,7 & 14,5 & 13,8 & 13,6 & 14,2 \\
Transferências & 3,6 & 3,9 & 4,7 & 5,4 & 5,6 & 5,1 & 5,4 & 5,3 \\
Subsídios & 0,1 & 0,2 & 0,2 & 0,5 & 0,5 & 1,1 & 0,7 & 0,7 \\
Investimentos & 2,7 & 4,6 & 3,4 & 3,3 & 4,8 & 5,6 & 5,2 & 5,7 \\
\hline TOTAL & 17,1 & 21,5 & 21,9 & 23,9 & 25,4 & 25,6 & 24,9 & 25,9 \\
\hline
\end{tabular}

Fonte: Plano Trienal de Desenvolvimento Econômico e Social (1963-1965)

Como se pode observar, a participação dos investimentos do setor público mais do que duplicou entre os extremos do período, refletindo, sobretudo nos anos de implementação do Plano de Metas, o grande esforço realizado pelo Estado na formação bruta de capital fixo, que teria crescido, segundo estimativas da FGV, de 25,6\% no período de 1953/56 para 37,1\% durante os anos de implementação do Plano.
A questão, entretanto, que no momento mais nos interessa, é a seguinte: qual a origem dos recursos que possibilitaram ao setor público a realização de tal esforço de investimento? Desde já cabe frisar que o total da arrecadação tributária sequer foi suficiente para cobrir os gastos com o consumo público, subsídios e transferências durante o período, como pode ser observado no quadro abaixo.

Tabela 2. Participação, no produto, da arrecadação tributária e dos gastos públicos, exclusive investimentos

\begin{tabular}{lccccccc}
\hline DISCRIMINAÇÃO & $\mathbf{1 9 5 0}$ & $\mathbf{1 9 5 5}$ & $\mathbf{1 9 5 6}$ & $\mathbf{1 9 5 7}$ & $\mathbf{1 9 5 8}$ & $\mathbf{1 9 5 9}$ & $\mathbf{1 9 6 0}$ \\
\hline $\begin{array}{l}\text { A) Arrecadação } \\
\text { tributária }\end{array}$ & 14,3 & 16,5 & 20,0 & 18,4 & 19,6 & 20,0 & 18,8 \\
$\begin{array}{l}\text { B) Consumo } \\
\text { público, subsídios e } \\
\text { transferências }\end{array}$ & 15,8 & 18,5 & 20,6 & 20,6 & 20,0 & 19,7 & 20,2 \\
\hline Porcentagem A/B & $\mathbf{9 0}$ & $\mathbf{8 9}$ & $\mathbf{9 7}$ & $\mathbf{9 0}$ & $\mathbf{9 8}$ & $\mathbf{1 0 1}$ & $\mathbf{9 3}$ \\
\hline
\end{tabular}

Fonte: Plano Trienal de Desenvolvimento Econômico e Social (1963-1965)

Parece claro que, do ponto de vista fiscal, o Estado estava desaparelhado para os investimentos previstos no Plano de Metas. A saída teria de ser outra.

A forma de financiamento dos investimentos do setor público, durante os anos de euforia desenvolvimentista, explica, em grande medida, a deterioração da situação financeira do país já nos últimos anos do Governo Kubitschek. A debilidade da base tributária, de um lado, e a ausência de um mercado de capitais que permitisse, junto ao setor privado, a captação do montante de recursos financeiros exigidos pelo crescimento das inversões estatais, de outro, levaram o Governo a uma saída não muito ortodoxa para o financiamento dos crescentes déficits de caixa: as emissões de papel-moeda.

O recurso a esse expediente fazia-se ainda mais necessário em decorrência das constantes reformulações operadas no mecanismo cambial com vistas a estimular o setor exportador. É que o Governo foi progressivamente eliminando o sistema de taxas múltiplas de câmbio e, junto com ele, uma importante fonte de recursos fiscais para o setor público, proveniente das receitas líquidas obtidas através das diferenças de câmbio. Para se ter uma idéia do que isso significou em termos de perda de arrecadação para o caixa do Tesouro, bas- 
ta mencionar que, em 1956, esses recursos representavam $42 \%$ da receita orçamentária, caindo para $2 \%$, em 1960, e desaparecendo completamente em 1961.

Assim, as emissões monetárias acabavam por se constituírem na única forma disponível de o Governo atuar no sentido de cobrir os seus déficits de caixa. O quadro abaixo resume a dramaticidade crescente da situação, nos anos relativos à implementação do Plano de Metas.

Tabela 3. Déficit de caixa orçamentário do governo federal e emissões de papel moeda (em Cr\$ bilhões)

\begin{tabular}{lccccccc}
\hline DISCRIMINAÇÃO/ANO & 1956 & 1957 & $\mathbf{1 9 5 8}$ & $\mathbf{1 9 5 9}$ & $\mathbf{1 9 6 0}$ & $\mathbf{1 9 6 1}$ \\
\hline $\begin{array}{l}\text { A) Déficit de caixa orcamentário do } \\
\text { Governo Federal }\end{array}$ & 27,8 & 39,8 & 26,5 & 53,7 & 77,7 & 130,4 \\
B) Emissões de papel-moeda & 11,5 & 15,8 & 23,2 & 34,8 & 51,5 & 107,8 \\
\hline PORCENTAGENS & & & & & & \\
\hline B/A & 41,4 & 39,7 & 87,5 & 64,8 & 66,3 & 82,7 \\
A/B & 3,1 & 3,8 & 2,1 & 3,0 & 3,2 & 3,7 \\
\hline
\end{tabular}

Fonte: Plano Trienal de Desenvolvimento Econômico e Social (1963-1965)

Feitas essas breves considerações sobre a forma pela qual se logrou obter recursos para o financiamento do ambicioso Plano de Metas, cabem agora alguns comentários acerca das consequiências derivadas da utilização desses esquemas de financiamento.

No que diz respeito às fontes originárias do capital estrangeiro, era de se esperar um crescente grau de endividamento externo, bem como uma constante elevação da remessa de lucros e dividendos dos capitais forâneos que aqui se instalaram durante o período do Plano de Metas. Foi o que de fato ocorreu. Isso redundaria, nos anos de implementação do Plano, num progressivo agravamento da situação do balanço de pagamentos, que, após 1956, apresentou-se deficitário em todos os anos restantes do Governo Kubitschek, obrigando o Governo a lançar mão de expedientes de regularização de curtíssimo prazo que apenas transferiam de maneira ampliada os problemas para os anos imediatamente seguintes.

Entretanto, é no front interno que se concentraram os principais desequilíbrios gerados. Estes, além de refletirem o agravamento da situação externa, eram também decorrentes do esquema de financiamento dos déficits estatais, oriundos do esforço de investimento realizado para a implementação do Plano de Metas. Tais desequilíbrios encontram sua síntese no fenômeno inflacionário. No primeiro ano de implementação do Plano de Metas, a taxa de inflação registrou um crescimento de apenas $7 \%$. Contudo, nos anos posteriores, a evolução foi a seguinte: $24,3 \%$, em 1958; $39,5 \%$, em 1959; 30,5\%, em 1960; 47,7\%, em 1961;
51,3\%, em 1962; e 81,3\%, em 1963.

Se o recurso à administração paralela representou a opção do Governo por uma linha de menor resistência diante das previsíveis dificuldades de uma ampla reforma administrativa, o fenômeno inflacionário foi o resultado também de uma opção por uma linha de menor resistência na dimensão do financiamento do Plano. Ainda conforme o já citado estudo de Benevides, "a inflação foi a alternativa mais viável para financiar o Programa de Metas e a construção de Brasília, uma vez que a reforma tributária (o que significaria meios coercitivos para levantar por vias fiscais amplos recursos de investimentos) seria politicamente impossível" (BENEVIDES, 1976, p. 236).

O agravamento da situação inflacionária a partir de 1958 colocou um grande problema para os formuladores e gestores da política econômica do Governo. Como obter a redução das taxas de inflação sem comprometer a implementação do Plano de Metas? Em que medida é possível conciliar um programa de estabilização com uma política de intenso desenvolvimento econômico?

\section{O PLANO DE ESTABILIZAÇÃO MONE- TÁRIA (1958-1959) E A ASCENSÃO DA META DA ESTABILIDADE}

Concebido por uma equipe chefiada por Lucas Lopes e Roberto Campos, os mesmos formuladores do Plano de Metas, o Plano de Estabilização Monetária (PEM) pode ser considerado a primeira tentativa de guinada na concepção da política econômica oficial. Ainda que tenha sido 
abandonado por força de reações políticas várias (como veremos a seguir), o fato é que esse Plano trazia para o âmbito do Governo o conflito, já então amplamente debatido nos meios técnicos, entre estabilidade e desenvolvimento. Mesmo que se admitisse correta a hipótese de que o PEM procurava a estabilização sem comprometer as políticas de desenvolvimento do Plano de Metas, não resta dúvida de que a sua proposição representou uma ascensão do objetivo "estabilidade" na escala de prioridades dos formuladores e gestores da política econômica. E sua trajetória mostrou as grandes dificuldades da conciliação desse objetivo com o até então predominante objetivo de desenvolvimento econômico.

Poucos meses antes do surgimento do PEM, ainda na gestão de José Maria Alkimin no Ministério da Fazenda, as autoridades governamentais brasileiras, através do referido Ministro, estabeleceram um acordo com o Fundo Monetário Internacional comprometendo-se com uma política antiinflacionária concebida dentro dos moldes estritos dos esquemas do Fundo. Em contrapartida à liberação de créditos stand-by do FMI, do EXIMBANK e de bancos privados norteamericanos, Alkimin comprometia-se a implementar uma política antiinflacionária de corte nitidamente ortodoxo, com as seguintes características: cortes indiscriminados dos gastos públicos (tanto nos gastos com o consumo corrente quanto nos gastos com investimentos), restrição salarial, reversão na política de financiamento dos estoques invendáveis de café ${ }^{4}$, suspensão dos créditos suplementares europeus e desmantelamento do sistema cambial adotado em 1956. Todas essas políticas eram evidentemente contrárias ao espírito do Plano de Metas. Como salienta SOLA (1982, p. 154), é até provável que Alkimin desconfiasse dessa incompatibilidade, mas também era incontestável o seu despreparo técnico, o que explicaria, juntamente com a grave situação externa do Brasil naquele momento, a efetivação do acordo como um ato de desespero em busca dos créditos externos.

\footnotetext{
4 Vale lembrar que a partir de 1956 iniciou-se um novo ciclo de superprodução de café, obrigando o Governo a seguir uma política de garantia dos preços do produto cuja conseqüência principal foi a geração de um importante foco de pressão inflacionária.
}

Em junho de 1958, cercado de críticas por ter fracassado na tarefa de obter novos financiamentos externos, além de ter agravado os problemas inflacionários e do balanço de pagamentos, José Maria Alkimin foi substituído pelo engenheiro Lucas Lopes.

O novo Ministro da Fazenda imediatamente percebeu a impossibilidade do cumprimento do acordo feito pelo seu predecessor sem o conseqüente abandono do Plano de Metas. Entretanto, o problema da estabilidade estava colocado e exigia uma resposta imediata das autoridades. Além das visíveis perturbações ocasionadas pela inflação no plano interno, havia a necessidade de dar uma resposta, no plano externo, à comunidade financeira internacional - representada principalmente pelo FMI - caso se pretendesse obter os financiamentos necessários à continuidade do programa desenvolvimentista de Kubitschek. Por uma e outra razão, os novos gestores da política econômica não podiam dispensar a tentativa de implementação de um plano de estabilização. $\mathrm{O}$ PEM (1958-1959) deveria cumprir essa função.

Do ponto de vista técnico, em que diferia o PEM do esquema de estabilidade firmado no acordo com o FMI? Basicamente no seu gradualismo. Como se sabe, os programas de estabilização do FMI eram invariavelmente baseados em "tratamentos de choque", ou seja, propunham uma redução abrupta da demanda global, através de expedientes como o corte indiscriminado no gasto público, forte restrição salarial, elevada contenção de crédito ao setor privado etc. No PEM, todos esses expedientes estão presentes de certa forma. Entretanto, a dosagem imposta à contenção da demanda global era bem menor e diluída no tempo. Essa terapia antiinflacionária é que caracteriza o chamado "gradualismo" no combate à inflação. Assim, ao invés do corte drástico nas emissões monetárias, proposto pelo Fundo, o PEM previa uma redução paulatina dessas emissões, de modo que de $15,3 \%$ previstos para 1958, estas deveriam reduzir-se a $10 \%$ em 1959, e a $5 \%$ em 1960. As razões para essa terapia gradualista estão ligadas à convicção firmada na época de que o tratamento de choque seria extremamente danoso ao processo de desenvolvimento. Esse é, por exemplo, o conteúdo da crítica feita por Roberto Campos às políticas do FMI, quando esse economista se referia à falácia agregativa apregoada por essa instituição. Haveria, segundo Campos, a necessidade de diferenciar 
dentre os gastos públicos aqueles destinados ao investimento dos gastos com consumo. Se era verdade que os gastos excessivos com consumo poderiam levar a uma elevação inflacionária da demanda global, também não se poderia desconsiderar a importância dos gastos do Estado com investimentos, sobretudo nos chamados "pontos de estrangulamento", para a continuidade do desenvolvimento. Sendo assim, qualquer política antiinflacionária que concebesse o gasto público agregadamente, isto é, sem a distinção salientada por Campos, estaria inevitavelmente impondo sacrifícios desnecessários ao crescimento econômico.

Embora as diferenças do PEM em relação ao programa do FMI fossem visíveis, a ponto do FMI ter adotado uma política de "esperar para ver", ao invés de apoiá-lo definitivamente, atendendo assim ao apelo dos formuladores do programa, tais diferenças não devem ser superdimensionadas, pois, "despite the gradualist strategy for combatting inflation and the balance of payments deficit, intented to deflect possible political resistence on the domestic front, the nature and the extent of the measures proposed seemed to meet the requirements of the IMF" (SOLA, 1982, p. 168). Em contrapartida, os formuladores do PEM esperavam o aval do Fundo para um novo empréstimo norte-americano de 300 milhões de dólares.

Contudo, justamente devido a esse seu caráter conciliador para com o capital estrangeiro representado pelo FMI, o PEM passou a sofrer uma grande reação, no plano interno, principalmente dos setores identificados com o nacionalismo. Skidmore resume bem o clima político daquela conjuntura: "a reação à pressão estrangeira estava muito disseminada. Augusto Frederico Schmidt, que Kubitschek enviou a Washington em 1958, a fim de auxiliar as negociações de um financiamento adicional, e que não era de modo algum esquerdista (defendia veementemente o investimento privado estrangeiro, por exemplo), atacou violentamente as exigências irrealistas do FMI. Entre alguns dos conselheiros de Kubitschek pairava um forte ressentimento quanto à recusa do Governo dos Estados Unidos em responder à Operação Pan-Americana, proposta um ano antes. [...] A reação antiamericana era compartilhada por toda a imprensa brasileira, inclusive entre elementos não exclusivamente 'nacionalistas'. Em maio de 1959, o vice-Presidente Goulart acusou os lucros excessivos das firmas de propriedade estrangeira de provocarem os problemas econômicos no Brasil, dando com isso novo reforço dentro do PTB à posição nacionalista extrema que Vargas tinha sempre endossado durante sua própria crise anti-inflacionária" (SKIDMORE, 1979, p. 222).

Além dessas reações mais difusas, movidas por princípios ideológicos, o PEM sofreu também a reação daqueles setores imediatamente afetados, em seus interesses econômicos e corporativos, com as políticas restritivas do Plano. Era o caso dos cafeicultores, que tiveram seus interesses feridos com a mudança da política protecionista de compra de excedentes de café para uma política de proteção mais austera. A maior demonstração de descontentamento desse setor em relação à nova política econômica foi planejada para ser executada em outubro de 1958, episódio que ficou conhecido como a "marcha da produção". Foi a tentativa dos cafeicultores paulistas de promover uma passeata motorizada, envolvendo milhares de veículos, que só não foi realizada devido à ação de bloqueio executada pelo Exército, cumprindo determinação do Ministro da Fazenda (SOLA, 1999, p. 205). O descontentamento desse setor fazia-se presente ainda em órgãos da grande imprensa, como no jornal O Estado de São Paulo, e sobretudo no Congresso Nacional, composto por inúmeros representantes dos cafeicultores.

Também os industriais opuseram-se às medidas impostas pelo PEM. A restrição do crédito bancário foi a principal fonte de descontentamento desse setor, que veiculava suas críticas à política econômica de Lopes e Campos através de periódicos como a revista Desenvolvimento e Conjuntura, órgão da Confederação Nacional da Indústria, no qual se propunha um programa de estabilidade com desenvolvimento, seguindo um caminho alternativo ao proposto pelo PEM.

Já os periódicos de caráter mais liberal como a revista Conjuntura Econômica e o Digesto Econômico - este último uma publicação técnica da Federação Comercial de São Paulo - passaram a mover uma campanha contra a "estatização", criticando sobretudo o grande poder atribuído ao BNDE no direcionamento das verbas do Plano de Metas, que dava prioridade aos investimentos públicos, fato que causava certo descontentamento no setor privado, ainda mais diante da restrição creditícia imposta pelo PEM.

Em face de todas essas formas de reação ao 
Plano de Estabilização Monetária, é compreensível que Kubitschek, um político com muitos interesses em jogo, mudasse sua posição em relação ao mesmo. A troco de que, afinal, comprometeria seus dois últimos anos de mandato presidencial com um programa de estabilização que até então só lhe tinha trazido dificuldades? Certamente, essa não seria a atitude mais aconselhável para um político que tinha a pretensão de, em breve, retornar à Presidência da República. Deveria evitar ser visto pela "Nação" como um fraco diante dos "interesses estrangeiros". E ainda assim, com ele correndo todos esses riscos políticos, o FMI continuava "esperando para ver", a Operação PanAmericana continuava sem resposta... Kubitschek não hesitou. Em junho de 1959, determinou que se encerrassem as negociações com o FMI, rompendo oficialmente com aquela instituição. Pouco depois, em agosto, desferia o golpe fatal no PEM, demitindo a equipe responsável pela elaboração e implementação do Plano. Lucas Lopes dava lugar a Sebastião Pais de Almeida, no Ministério da Fazenda, enquanto Roberto Campos era substituído por Lúcio Meira, no BNDE.

\section{O INTERREGNO QUADROS E A REFOR- MA CAMBIAL DE 1961}

Em janeiro de 1961, a UDN, principal partido de oposição à política varguista, saiu vitoriosa, pela primeira vez desde sua criação, de uma eleição presidencial. Endossando a candidatura de um político carismático e com forte apelo populista, filiado ao inexpressivo PTN (Partido Trabalhista Nacional), o eterno "Partido da Oposição" parecia disposto a riscos e sacrifícios para a conquista do poder. Porém, para a preocupação dos udenistas, Jânio Quadros, o novo Presidente, não era o que se poderia chamar de um "homem de partido". Sua carreira política foi marcada pelo seu espírito populista, temperado com uma grande dose de imprevisibilidade em seus atos. Irreverente e intempestivo, elegeu-se com o discurso de moralização do país, apoiado por políticos como Carlos Lacerda e Magalhães Pinto, que certamente sabiam os riscos de apoiar tal candidatura. As palavras de Magalhães Pinto, na convenção da UDN que homologou o nome de Quadros, deixam transparecer a preocupação desse líder udenista em relação à imprevisibilidade de Quadros: “O deputado Jânio Quadros, ao aceitar sua candidatura pela legenda do partido de Eduardo Gomes [...] assume, perante a Nação, graves responsabilidades. Responsabilidade que lhe põe nas mãos o maior partido de homens livres do Brasil - o Partido da Oposição. A responsabilidade de enfrentar como líder popular uma campanha que se travará num ambiente de perplexidade e de crise. Crise institucional. Crise política. Crise econômico-financeira. Crise de desenvolvimento. Crise social" (VICTOR, 1965, p. 53). A responsabilidade na qual tanto insiste Magalhães Pinto reflete, a nosso ver, o receio à imprevisibilidade de Quadros. Em seu curto período de Governo, ele apenas confirmou esse seu caráter imprevisível, conseguindo rapidamente transformar seus aliados de campanha em inimigos políticos.

Com a negativa de Kubitschek em seguir qualquer programa antiinflacionário após a falência do PEM, a situação econômico-financeira deteriorou-se bastante nos dois últimos anos de seu Governo. Devido à redução da entrada de créditos externos com longos prazos de amortização que se seguiu à ruptura entre o Governo e o FMI, passou a predominar, como vimos, a contração de empréstimos a serem amortizados no curtíssimo prazo, grande parte dos quais vencendo no primeiro ano de Governo de Jânio Quadros. O Presidente eleito não deixou passar despercebida a responsabilidade de seu antecessor na geração da grande crise econômico-financeira que ele teria de enfrentar. Em seu discurso de posse, realizado em 31 de janeiro de 1961, Quadros esboça o quadro financeiro que herdara: "É terrível a situação financeira do Brasil. Nos últimos cinco anos, o meio circulante passou de 57 bilhões para 206 bilhões de cruzeiros [...] devemos ao estrangeiro 3 bilhões e 802 milhões de dólares, o que marca, só a este título e naquele período, a elevação de 1 bilhão e 435 milhões de dólares sobre o passivo anterior. E a situação é tanto mais séria quando se sabe que, somente durante o meu Governo, devemos saldar compromissos em moeda estrangeira no total de cerca de 2 bilhões de dólares" (apud VICTOR, 1965, p. 80-81).

Jânio Quadros, que negava qualquer papel positivo à inflação, estando suas concepções econômicas mais próximas dos "monetaristas" do que dos "estruturalistas" 5 Na conjuntura do início dos anos sessenta, o controle
sobre a política econômica oficial, principalmente sobre
a política antiinflacionária, era disputado por basicamente 
sua campanha eleitoral, com a restituição da "verdade cambial" como principal expediente para acabar com a inflação. Coincidentemente (ou não), a reforma cambial era um dos requisitos sempre recorrentes do FMI para a efetivação de seus acordos com o Brasil. Seguramente, naquele momento, o reatamento das relações brasileiras com aquela instituição passaria pelo cumprimento da exigência de mudança no mecanismo de câmbio.

A opinião da elite empresarial passou a fortalecer as intenções de Quadros a esse respeito. No início de março, uma delegação do CONCLAP (Conselho das Classes Produtoras) entregou ao Presidente um documento contendo sugestões para um plano de desenvolvimento, no qual se destaca a necessidade imperiosa de liberalização do câmbio (CORREIO DA MANHÃ, 07/03/1961). Logo em seguida, o Correio da Manhã, importante jornal carioca, publicou editorial incentivando Quadros a tomar tal atitude (CORREIO DA MANHÃ, 08/03/1961).

Finalmente, no fim da primeira quinzena de março, Quadros apareceu em cadeia de rádio e TV para apresentar as novas medidas ao público. Inicialmente, fez um resgate das medidas de economia que já estava colocando em prática: "As duas jornadas do funcionalismo, o corte de $30 \%$ nas despesas ministeriais e autárquicas, o rigor im-

duas correntes do pensamento econômico da época. De um lado, os "monetaristas", afirmando que as causas da inflação eram essencialmente de ordem monetária, resumindo-se, em última análise, ao crescimento da oferta monetária em proporção superior ao crescimento da produção real. Desse modo, a terapia preconizada pelos "monetaristas" centrava-se na idéia de um comportamento rigoroso das autoridades monetárias em relação ao déficit público, à oferta de crédito, à expansão do meio circulante, além da política de compressão dos salários. Os "estruturalistas", por outro lado, sustentavam que tais medidas representavam apenas expedientes superficiais no combate às reais causas da inflação. Para esta corrente de economistas, em geral ligados à escola da CEPAL, a inflação seria, para além de um fenômeno puramente monetário, um fenômeno decorrente de desajustamentos estruturais inerentes ao desenvolvimento econômico dos países subdesenvolvidos. Assim, a única terapia antiinflacionária capaz de combater as causas da inflação seria a realização de um conjunto de "reformas estruturais", destacando-se a reforma agrária, a reforma fiscal progressiva, a reforma administrativa e a reforma bancária. Para maiores detalhes sobre esta controvérsia ver: HIRSCHMAN (1967), CRUZ (1980), SILVA (1992). posto nas despesas industriais do Governo e, por isso, do povo, a redução dos gastos das forças armadas, inclusive em sua representação no exterior, a diminuição dos vencimentos dos diplomatas e a supressão dos escritórios comerciais são exemplos de economia". Em seguida Quadros acrescentou: "Mas a volta à realidade salarial deve ser complementada pela eliminação da mentira do câmbio. O problema cambial de longo prazo no Brasil é o da insuficiência crônica das nossas exportações que até diminuem - ao passo que cresce continuamente a necessidade de importar quantidades cada vez maiores de combustível, matérias-primas e mesmo de alimentos. O problema imediato deste ano e do próximo será insolúvel sem a cooperação ou ajuda financeira internacional" (CORREIO DA MANHÃ, 14/03/1961). Vejamos em que consistia basicamente a Reforma.

Implementada pela Instrução $n^{\circ} 204$ da SUMOC, a Reforma eliminou o sistema de taxas múltiplas de câmbio e instituiu uma taxa única de mercado para todas as transações comerciais (excetuando-se apenas café e cacau). O câmbio de custo (taxa cambial subsidiada) dobrou seu valor, passando de 100 para 200 cruzeiros por dólar, o que reduzia em muito o subsídio àquelas importações que permaneciam na categoria preferencial, como trigo, petróleo, papel de imprensa, fertilizantes, inseticidas e bens de capital não produzidos internamente. "A reforma, por outra parte, destinava-se a reequacionar as condições de financiamento do setor público, cujos déficits eram vistos como um dos principais responsáveis pelas elevadas taxas de inflação observadas no período. Neste sentido foi instituído o depósito prévio às importações que, ademais de operar como instrumento de discriminação, representava uma fonte adicional de recursos para o setor público. Além disso, foi criado o recolhimento obrigatório sobre exportações que significava, na prática, a formalização de um esquema de tributação sobre as exportações. Por fim, o simples reajustamento da taxa de câmbio dava origem a uma maior arrecadação do imposto de exportação" (CRUZ, 1980, p. 15). Assim, apesar da Reforma eliminar uma importante fonte de recursos para o Tesouro, proveniente do sistema de leilões de cambiais, o efeito imediato tanto para o orçamento público quanto para o balanço de pagamentos parece ter sido positivo ${ }^{6}$.

6 "The elimination of the auction system, which had 
No plano externo, as medidas efetuadas por Jânio Quadros foram vistas com bons olhos pela comunidade financeira internacional. Prova disso foi o sucesso das negociações que se realizavam com os bancos americanos e europeus, pelos embaixadores Walter Moreira Sales e Roberto Campos, respectivamente. A missão norte-americana foi particularmente bem-sucedida, apresentando, segundo Sochaczewski, os seguintes resultados: "From the IMF Brazil was granted a stand-by credit of US\$ 160 million and roll-over of previous compensatory loans due in 1961. From the EXIMBANK a US\$ 168 million credit was obtained together with the re-scheduling of US\$ 212 million of compensatory loans and US\$ 92 million debts from Banco do Brasil with the American bank. A US\$ 100 million credit was even granted by IDA which wasn't yet entirely established. From private banks Brazil got a US\$ 48 million credit apart from rolling-over US\$200 million from the 1954 loan and consolidating commercial arrears to oil suppliers to the amount of US\$ 45 million" (SOCHACZEWSKI, 1980, p. 193; grifo no original).

A missão européia, por seu turno, embora menos produtiva, ainda obteve créditos stand-by no montante de 110 milhões de dólares, além de conseguir uma rolagem de dívidas anteriores no valor de 170 milhões de dólares.

$\mathrm{O}$ resultado dessas negociações, conjugado com o incremento das exportações devido às medidas da Reforma Cambial, foi a sensível melhora do balanço de pagamentos que se mostrou superavitário em 1961.

Também imediatamente após a promulgação da Instrução $n^{\circ} 204$, a elite empresarial parece ter tido uma reação bastante favorável às novas medidas. Rui Gomes de Almeida, presidente da Associação Comercial do Rio de Janeiro, defendeu a medida dizendo que eram "velhas aspirações das

generated financial resources for the government in the past, was counter-balanced by the fiscal measures linked to the exchange reforms. The compulsory sale of import bills produced an additional $\mathrm{Cr} \$ 67 \mathrm{~m}$ in 1961, and the increase of 100 per cent in the price of foreign exchange for subsidized imports meant that taxes on imports generated $\mathrm{Cr} \$ 37,7 \mathrm{~m}$ in 1961, in comparison with $\mathrm{Cr} \$$ $22 \mathrm{~m}$ in 1960; an increase of 64 per cent compared with an increase of only 34 per cent in external taxes" (SOLA, 1982, p. 216). classes produtoras". Enquanto isso, o presidente do CONCLAP, Enéas Almeida Fontes, dizia o seguinte sobre a medida: "Aplaudo, como Presidente do CONCLAP, a Instrução 204, e estou certo de que as classes produtoras - comércio, indústria, bancos, seguradoras, das categorias de empregados e empregadores, enfim, todos quantos são representados pelo CONCLAP - encontramse dispostos a formar na primeira linha para assegurar, na área do livre empreendimento, o êxito das medidas contidas na Instrução" (CORREIO DA MANHÃ, 15/03/1961).

Entretanto, a reação da elite política não foi das mais positivas com relação à Reforma, sobretudo entre aqueles situados no campo nacionalista. A medida foi vista como uma inteira submissão aos interesses do FMI, despertando reações críticas mesmo de políticos não tão radicais em seu nacionalismo como José Maria Alkimin, que teria dito na ocasião em que tomou conhecimento da medida: "Este Governo não durará muito" (apud SOLA, 1982, p. 219). Inclusive os militares publicaram um manifesto criticando a política de Quadros, dentre outras coisas, por ser lesiva aos "interesses da Nação".

Porém, o mais contundente golpe na política de estabilização de Quadros adveio dos próprios efeitos adversos que a Reforma gerou no ritmo inflacionário. Com a eliminação dos subsídios à importação de trigo e petróleo, os preços internos desses produtos subiram imediatamente, depreciando muito a popularidade do Presidente.

Quadros procurava neutralizar essas reações que se esboçavam no campo nacionalista e popular, executando a chamada "política externa independente". Esta consistia em um nãoalinhamento automático no conflito que opunha os blocos capitalista e socialista. Essa orientação do Itamarati provocou, em diversos momentos, a irritação do Governo norte-americano, como na questão cubana, ao mesmo tempo em que, internamente, desencadeou as reações da direita civil e militar, que via na aproximação do Brasil com os países socialistas a traição de seus "ideais cristãos e democráticos".

Atacando "valores" e "interesses" da esquerda e da direita, Quadros parecia querer colocar-se acima desses extremos do espectro político. Ao mesmo tempo em que realizava a política econômico-financeira ortodoxa, cuja expressão máxima, além dos apertos creditício e salarial, foi a 
Instrução $n^{\circ} 204$, despertando a reação à esquerda, Quadros chegava mesmo ao limite da provocação gratuita para com a direita, como no episódio da condecoração do líder revolucionário Ernesto Guevara, com a Ordem do Cruzeiro do Sul. Parecia querer travar seus embates políticos somente na arena internacional. Aos políticos locais nada teria a dizer. Depositava extremada confiança nos quase seis milhões de votos que obtivera. Mas não se perguntou, senão quando já era tarde demais, se o "povo" ainda estava com ele. A verdade é que por detrás da aparente fortaleza que suas atitudes sugeriam, ocultava-se uma situação, de fato, de extrema fragilidade política. A suposta vocação para o diálogo com as demais nações era apenas reflexo invertido de uma incapacidade quase absoluta para o diálogo com as forças políticas na arena interna. Conforme notou um analista político na época: "Durante todo o seu Governo, e antes mesmo dele, o Sr. Jânio Quadros insistiu em se colocar acima da direita e da esquerda, numa posição de árbitro a distribuir justiça salomônica [...], mas sem contar com uma força política própria ou com um dispositivo militar convertido às suas idéias e à sua ação. Seu equilíbrio político era, portanto, extremamente instável" (MARTINS, 1962, p. 10). E o ponto crítico dessa instabilidade manifestou-se no episódio de sua renúncia. Independentemente de suas veleidades conspiratórias, o ato de Quadros deve ser entendido como o resultado da debilidade de sua situação política. Praticou, de fato, um "suicídio sem sangue". Mas o "povo", acostumado a emoções mais intensas, não se sentiu estimulado a sair às ruas clamando por seu nome ${ }^{7}$.

\section{O PLANO TRIENAL E A TENTATIVA FRUSTRADA DE CONCILIAÇÃO}

A renúncia do Presidente Quadros, em agosto de 1961, abriu um período de crise que só seria encerrado com o golpe militar de 1964. O país ingressava em uma conjuntura que combinaria, em doses crescentes, radicalização e polarização política e ideológica com o aprofundamento da crise econômica.

A consequiência imediata da renúncia foi uma grave crise política e institucional que lançou o

7 Sobre a evolução dos acontecimentos que se anteciparam à renúncia de Quadros, ver: VICTOR (1965); BANDEIRA (1979); AFFONSO (1988). país à beira de uma guerra civil. Talvez em oposição às reais intenções de Quadros, o Congresso aceitou imediatamente seu pedido de renúncia e o povo não saiu às ruas clamando por seu nome. Tendo em vista o fato de que, naquele momento, o vice-Presidente João Goulart encontrava-se em visita à China comunista, o Congresso empossou Ranieri Mazzili, Presidente da Câmara dos Deputados e sucessor constitucional na ausência do vice-Presidente.

No mesmo momento em que Goulart decidiu retornar rapidamente ao Brasil para assumir o cargo que a Constituição lhe conferia, os Ministros militares divulgam um manifesto ao país no qual procuram apresentar as razões da "absoluta inconveniência, na atual situação, do regresso ao país do vice-Presidente" (apud VICTOR, 1965, p. 348). Abriu-se com isso o episódio que ficou denominado a "crise da legalidade". Dispuseramse em lados opostos os favoráveis e os radicalmente contrários à posse de Jango. Desafiando frontalmente as intenções da alta hierarquia militar, um amplo conjunto de organizações e forças políticas articularam-se para garantir o apoio ao cumprimento da Constituição e a posse de Goulart. Leonel Brizola, governador do Rio Grande do Sul, cunhado e correligionário de Jango, orquestrava a "rede da legalidade", que transmitia, via rádio, discursos inflamados incitando a população a garantir, com armas se necessário, a posse do vice-Presidente.

O Palácio Piratini, sede do Governo gaúcho, tornou-se o foco da resistência legalista. Porto Alegre era uma cidade sitiada naqueles dias do fim de agosto de 1961, uma cidade preparada para a guerra civil. A campanha pela legalidade conquistava um crescente número de adeptos entre intelectuais, governadores de estados, estudantes, trabalhadores urbanos, camponeses etc. Mas a principal adesão foi a do comando do III Exército, chefiado pelo General José Machado Lopes.

O III Exército, que comandava as tropas situadas nos três estados da região sul, declarouse insubordinado às ordens do Ministro da Guerra. Isto ocorreu no exato momento em que o ministro deu ordens de bombardear o Palácio Piratini com vistas ao desmantelamento da resistência encabeçada por Brizola. O general Machado Lopes reagiu prontamente, afirmando que não mais cumpriria as ordens de seus superiores hierárquicos. E ainda mais: resistiria lutando ao lado do povo e do gover- 
nador Brizola e só obedeceria as ordens do chefe constitucional das forças armadas, o Presidente Goulart.

Imediatamente o Ministério da Guerra divulgou uma nota à imprensa na qual se afirmava que "o Exército está coeso em torno da autoridade do Ministro da Guerra e conta com o apoio unânime das outras Forças Armadas". Mas de fato o que ocorria era um processo de cisão crescente no interior das Forças Armadas. Além do III Exército, as forças legalistas ganhavam a adesão de uma série de outras forças militares dissidentes do comando geral das forças armadas, como foi o caso dos oficiais do $2^{\circ}$ Batalhão de Caçadores de São Paulo. Estava, assim, aberta a possibilidade de o conflito explodir no campo militar, o que significaria, de fato, o estopim de uma guerra civil cujas consequiências seriam imprevisíveis.

O temor da imprevisibilidade e das soluções radicais ou sangrentas, típico da elite política brasileira, fez que, uma vez mais, se pusesse em prática o mecanismo da conciliação interelites. Tal mecanismo consubstanciou-se no Ato Adicional que alterava o sistema de Governo definido na Constituição de 1946. Em rigor, a possibilidade de uma solução de compromisso em torno da alteração do sistema de Governo já havia sido encaminhada, implicitamente, pelos mesmos ministros militares que se opuseram à posse de Goulart. Pode-se ler no manifesto por eles divulgado que a ameaça representada por Jango ligava-se ao lugar que este ocuparia na Presidência da República, "em regime que atribui ampla autoridade e poder pessoal ao Chefe de Governo" (apud VICTOR, 1965, p. 348). Goulart assumiria a Presidência, mas com os poderes ceifados o suficiente para, na visão dos militares, amenizar sua presença ameaçadora.

A solução encontrada para crise resolvia um problema mas criava outro. De que fonte poderia surgir a legitimidade do Primeiro Ministro e de seu gabinete para encaminhar as difíceis soluções para os problemas econômicos e sociais daquela conjuntura crítica? Nascido de uma manobra conservadora, o "gabinete de união nacional" encabeçado pelo Primeiro-Ministro Tancredo Neves não pôde fazer mais do que cumprir seu destino, experimentando um final melancólico após alguns meses de ingovernabilidade. Iguais destinos tiveram os outros dois gabinetes que $o$ sucederam. A letargia era tamanha no processo decisório que levou Hermes de Lima, último Premiê do interregno parlamentarista, a referir-se da seguinte maneira ao Governo de seu antecessor Brochado da Rocha: "Este Governo não é de extrema direita nem de extrema esquerda, mas de extrema-unção" (apud CASTELLO BRANCO, 1975, p. 26).

Em face da indisfarçável inoperância dos Governos parlamentaristas, o congresso viu-se compelido a ceder às pressões que se intensificavam para a realização de um plebiscito sobre o sistema de Governo. Assim, em janeiro de 1962, Goulart recuperou todos os poderes de Presidente da República, respaldado na vitória esmagadora da opção presidencialista. Foi nesse contexto que apareceu a derradeira tentativa de planejamento econômico nos marcos do regime democrático da Constituição de 1946: o Plano Trienal de Desenvolvimento Econômico e Social (1963-1965).

O Plano Trienal, obra de uma equipe de técnicos chefiada pelo economista Celso Furtado, teve sua inspiração inicial durante a campanha de Goulart para o plebiscito. Durante a vigência do parlamentarismo, a política econômica não apresentou maiores alterações, não indo além de medidas isoladas como o congelamento do depósito prévio de importação, a elevação do compulsório dos bancos comerciais etc. Foram também iniciadas tentativas de retomada das negociações com o Governo dos EUA. Na verdade, os três gabinetes que se sucederam no interregno parlamentarista jamais reuniram força política o bastante para ir além desses expedientes de política econômica.

Em setembro de 1962, Goulart procurou Celso Furtado, então Superintendente da SUDENE, dirigindo-se a ele com as seguintes palavras: "Quero que você assuma o Ministério Extraordinário do Planejamento. Vamos ter de nos preparar para o plebiscito, que devolverá os poderes ao Presidente, e quero me apresentar aos eleitores com um plano de Governo nas mãos" (apud FURTADO, 1989, p. 153).

A situação econômica com a qual se defrontara Celso Furtado era bastante preocupante. No ano de 1962, a taxa de crescimento do PIB reduziu-se a praticamente metade da obtida no ano anterior, caindo de $10,3 \%$ para $5,2 \%$. Paralelamente, a taxa de inflação saltara para além de 50\%, confirmando uma tendência de crescimento que se apresentava desde 1958. 
Todavia, a manutenção do crescimento econômico e a conquista da estabilidade monetária não eram os únicos desafios postos à imaginação dos planejadores naquela conjuntura. Cada vez mais freqüentes e intensas eram as mobilizações pelas chamadas "reformas de base". A reforma agrária era a bandeira que possuía maior poder de mobilização dos setores populares, mas também mobilizavam a opinião pública as demandas por reformas no sistema de tributação, no sistema bancário, na administração pública, nas universidades etc.

O Plano Trienal representa a primeira tentativa de tratar de maneira integrada e global as demandas conflitantes de desenvolvimento, estabilidade e reformas de base. Conforme assinala Ianni, "o Plano Trienal [...] foi o primeiro instrumento de política econômica global e globalizante, dentre todos os formulados até então pelos diversos Governos do Brasil. Em comparação com os planos, programas, comissões, institutos, departamentos e superintendências criados pelos Governos anteriores, o Plano Trienal correspondeu a uma fase mais avançada de elaboração conceptual e analítica" (IANNI, 1986, p. 209).

Mas os avanços "técnicos" do Plano não seriam o bastante para preencher a lacuna deixada por sua fragilidade política. Não poderia ser maior a distância entre o caráter ambicioso da solução global proposta pelo Plano Trienal e a escassez de recursos de poder do Governo Goulart. A estratégia posta em prática no Plano parecia sustentarse num apelo à conciliação entre forças políticas e sociais já àquela altura suficientemente polarizadas para que a estratégia dos planejadores caísse num vazio político.

Não obstante, os planejadores tiveram o cuidado de formular um conjunto de medidas de curto e médio prazo para o tratamento de cada um dos três grandes problemas da crise do início dos anos sessenta. A tarefa mais imediata, segundo os planejadores, era "planejar a estabilização em condições de desenvolvimento", ficando para "uma fase subseqüente, planejar a intensificação do desenvolvimento sem comprometer a estabilidade" (PLANO TRIENAL, 1962, p. 18). Tal precedência cronológica da meta de estabilidade conduziu o Governo a comprometer-se com uma política econômica antiinflacionária que previa, dentre outras medidas, a restrição creditícia, a eliminação de subsídios ao consumo, sobretudo de trigo e petróleo, e a redução do gasto público, sobretudo pela via da contenção dos reajustes salariais dos funcionários. Medidas dessa natureza representariam o teste de fogo do Plano Trienal. Ou se alcançava os resultados almejados nessa área, ou o Plano Trienal não conseguiria dar seu primeiro passo, comprometendo-se toda a estratégia.

A anterioridade estabelecida para o cumprimento da meta da estabilização era decorrente de uma situação que rapidamente fugia ao controle do Governo. A taxa de inflação, que chegara a mais de 50\% em 1962, era projetada para algo superior a $100 \%$ no ano de 1964 . Um cenário preocupante, tendo em vista o fato de que a redução do ritmo inflacionário não somente era uma demanda da população que protestava quanto ao aumento da "carestia", como também, e principalmente, uma exigência das agências financeiras internacionais para a retomada dos fluxos de capitais estrangeiros ao país, preocupação central na estratégia dos planejadores.

Aqui é necessário que nos detenhamos brevemente em algumas interpretações relevantes sobre o significado político do Plano Trienal. A tese predominante, que vê o Plano Trienal como um autêntico ensaio de pacto social de orientação social-democrata, deve ser consideravelmente matizada. Sem dúvida, como se depreende, por exemplo, dos estudos de SOLA (1998) e FIGUEIREDO (1993), o Plano Trienal pode ser interpretado como uma tentativa de alcançar uma saída dentro do marco institucional da democracia populista para a crise do início dos anos sessenta, acenando para o atendimento parcial das demandas dos diferentes grupos sócio-econômicos em conflito naquela conjuntura crítica. "O Plano Trienal pode ser visto como uma tentativa por parte do Governo de promover um acordo (e eventualmente um pacto) entre grupos comerciais e industriais, por um lado, e trabalhadores, por outro" (FIGUEIREDO, 1993, p. 92). Assim, o sucesso do Plano dependeria "da habilidade do Governo em formar uma coalizão multiclassista baseada em concessões e acordos mútuos" (idem, p. 93).

Mas é preciso qualificar a estratégia conciliadora do Plano Trienal. Se é verdade que os planejadores tiveram de indicar para os diferentes grupos sociais estratégias de realização de suas principais demandas, também deve-se considerar 
o fato de que tais demandas foram contempladas de modo desigual e conflitante no Plano Trienal. Assim, não nos parece aceitável a afirmação de que "os objetivos contemplados no Plano Trienal eram consensuais" (FIGUEIREDO, 1993, p. 92). É certo que o problema da inflação incomodava a todos, mas não da mesma maneira e nem na mesma intensidade. Já no que diz respeito à aceitação do objetivo de realização das reformas de base, o que a conjuntura do início dos anos sessenta evidencia é um radical desentendimento entre as forças políticas em conflito. Não faltava, dentre as vozes mais influentes no debate políticoeconômico, quem considerasse o assunto uma "balela", como o "decano dos economistas brasileiros", Eugênio Gudin, que afirmava, com o intuito de desqualificação dos defensores das reformas, que "é preciso ser integralmente (não parcialmente) imbecil para acreditar que essas reformas, quase todas desaconselháveis, aliás, possam ter qualquer influência sobre o progresso econômico e social do País" (GUDIN, 1965, p. 128). E acrescentava que "planejar o combate à inflação é o único planejamento por que anseia o País" (idem, p. 437).

Assim, longe de serem consensuais, os objetivos expostos no Plano Trienal eram conflitantes. Os setores que vocalizavam mais enfaticamente a demanda de estabilidade não eram os mesmos que empunhavam a bandeira das reformas de base. Frente a esse conflito, como interpretar a estratégia contida no Plano Trienal? A ênfase no caráter conciliador dessa estratégia não deveria encobrir o fato de que tal conciliação fazia-se em benefício dos setores conservadores do espectro político e ideológico, incondicionais defensores da estabilidade monetária, tendo em vista que, quer na dimensão do discurso técnico exposto no documento, quer na dimensão da ação efetiva dos planejadores com vistas à sua implementação, o Plano Trienal reduzira-se a um plano de estabilização. Tal constatação não pretende renunciar à tese que advoga o caráter conciliador do Plano, mas sugere a qualificação dessa tese.

Ao proceder-se à leitura do documento-síntese do Plano Trienal, é difícil escapar à conclusão de que as demandas pelas reformas de base, veiculadas mais intensamente pelas organizações das classes populares e por setores nacionalistas e de esquerda, receberam um tratamento apenas superficial, permanecendo muito aquém de constituírem-se como objeto de um planejamento detalhado e viável, diferentemente do que ocorrera com a demanda pela estabilidade monetária. No documento de quase 200 páginas, pouco mais do que seis páginas são dedicadas às "Diretrizes para as Reformas de Base Requeridas pelo Desenvolvimento Econômico". Como destacou o economista Werner Baer, ao analisar o Plano quando de sua publicação, em dezembro de 1962: "A decepção mais grave ocorre no final do plano, quando o leitor espera encontrar um grande clímax, ou seja, as recomendações sobre a política a ser adotada. As reformas bancária, administrativa e agrícola são objetos de recomendações simbólicas e jornalísticas, nuns poucos parágrafos superficiais" (BAER, 1962, p. 111).

Além disso, é necessário lembrar que as autoridades dos Ministérios do Planejamento e da Fazenda, responsáveis pelo Plano Trienal, não possuíam prerrogativas decisórias em torno das questões atinentes às reformas de base. Cabia ao Congresso Nacional e não ao poder Executivo deliberar sobre o assunto. Os instrumentos de política econômica sob o controle direto do Executivo limitavam-se às políticas monetária, cambial e, em menor medida, fiscal. Com tais instrumentos, tudo o que o Governo poderia almejar era uma política antiinflacionária de estilo tradicional, inspirada, quase inteiramente, no receituário monetarista de combate à inflação. É certo que as medidas propostas, sobretudo no que diz respeito à contenção do crédito e do gasto público, estavam ainda distantes do "tratamento de choque" advogado à época pelo FMI, principal centro de difusão do pensamento monetarista. Entretanto, o "gradualismo" no combate à inflação já havia sido experimentado no PEM e seria novamente posto em prática pelo PAEG (Plano de Ação Econômica do Governo 1964-1966), ambos elaborados sob o comando do "monetarista" Roberto Campos.

Em seu aprofundado estudo sobre o significado político da política econômica do Plano Trienal, Lourdes Sola procura minimizar as semelhanças entre o PEM e o PAEG, de um lado, e o Plano Trienal, de outro. Afirma que "apesar das semelhanças com os planos de 1958 e 1965, tanto o diagnóstico da crise brasileira quanto a estratégia econômica subjacente ao Plano Trienal, o credenciam como um produto genuíno da tradição cepalina. [...] ele é indicativo do compromisso explícito dos estruturalistas com objetivos de cunho social e com o desempenho da função reformadora do Estado, isto é, com objetivos social- 
democratas" (SOLA, 1998, p. 259-260).

Tal interpretação tende a ver no Plano Trienal algo mais do que ele de fato representou. $\mathrm{O}$ fato do Plano ter sido formulado sob a liderança do economista Celso Furtado, um dos mais expressivos representantes da "tradição cepalina", não nos parece evidência o suficiente para demonstrar a fidelidade do Plano Trienal à estratégia estruturalista de desenvolvimento econômico e combate à inflação. De modo algum pretendemos afirmar que a presença de Furtado no comando da equipe de elaboração do Plano fora de todo supérflua na sua definição, como aliás fica evidente na linguagem em que se produz o diagnóstico dos problemas que o Plano pretendia enfrentar. A forte ênfase dada aos obstáculos estruturais ao desenvolvimento econômico brasileiro, a exemplo da "deficiente estrutura agrária do País" (PLANO TRIENAL, 1962, p. 140), é um aspecto que diferencia o Plano Trienal das experiências de estabilização encabeçadas por Roberto Campos, antes e depois do experimento de Furtado. Porém, o que é decisivo é saber a medida em que o diagnóstico se traduz em políticas. E mais: saber em que medida o diagnóstico estruturalista conformaria a primeira fase do Plano, voltada para as políticas de estabilização.

É preciso ainda destacar que, em momentos de crise política, a percepção de tempo dos atores políticos é profundamente alterada. A aceleração do tempo político fortalece ainda mais a predisposição natural dos atores de orientarem suas ações no horizonte do curto prazo, voltando aos cálculos de médio prazo uma preocupação remota e aos de longo prazo, o esquecimento. Portanto, na avaliação do significado político do Plano Trienal, a precedência cronológica do atendimento da meta da estabilidade não é de menor importância. O que a maioria dos grupos sociais podia perceber diante de si, naquela conjuntura de crise, era um plano de estabilização com medidas que lhes exigiam mais "sacrifícios" num momento de profunda recessão.

Embora o diagnóstico da economia brasileira apresentado no Plano fosse pautado pelas principais teses estruturalistas, parece-nos que as políticas antiinflacionárias não puderam dispensar os recursos terapêuticos desenvolvidos pelos monetaristas. Negar que o resultado da implementação parcial das políticas de estabilização foi a contração da demanda global e o aprofun- damento da recessão seria entrar em guerra inútil contra as estatísticas. Conforme observou John Wells, "the cycle of expansion in Brazilian economy, begun in mid-fifities, was brought to an abrupt end by the Furtado-Dantas Plano Trienal implemented in early 63; the industrial recession began no earlier than 1963 , but once it ocurred it affected all sectors of activity simultaneously" (WELLS, 1977, p. 226).

A estratégia de estabilização centrada na redução da demanda global não era típica da corrente estruturalista de abordagem da inflação. Ao contrário, eram os monetaristas que insistiam na inevitabilidade da terapia recessionista. No intenso debate que se travou no início dos anos sessenta em torno das causas do fenômeno inflacionário e das terapias recomendadas para seu tratamento, os estruturalistas inovaram por recusarem todo programa de estabilização que se ativesse somente aos fenômenos superficiais do processo inflacionário. Advogavam que as reais causas da inflação originavam-se em desajustamentos e inelasticidades da estrutura econômica e social típica dos países subdesenvolvidos e que a inflação somente poderia ser definitivamente vencida se fossem realizadas reformas estruturais de caráter redistributivo, tais como uma reforma fiscal progressiva e a reforma agrária. Ainda mais: advogavam que seria menos prejudicial conviver com um certo nível de inflação do que a submissão às políticas restritivas geradoras de recessão recomendadas então pelo FMI.

Quanto à importância de se considerar os desajustamentos e as inelasticidades da estrutura econômica dos países subdesenvolvidos no diagnóstico das causas da inflação, tarefa tão bem executada no Plano Trienal, devemos considerar o que pensavam os monetaristas. Estes, através de seu expoente, o economista Roberto Campos, propunham uma saída conciliatória para o debate em torno da inflação, a qual se resumia na incorporação da capacidade analítica desenvolvida pelos estruturalistas em benefício da terapia antiinflacionária ortodoxa. Campos argumentava que "a identificação de pontos de estrangulamentos é evidentemente de grande utilidade para que a política fiscal e monetária tenha um papel ativo ainda mais útil; e esta é a linha de reconciliação entre monetaristas e estruturalistas" (CAMPOS, 1967, p. 92). Enquanto os monetaristas cediam no plano do diagnóstico da infla- 
ção, mantendo intacto o cerne de suas terapias antiinflacionárias, os estruturalistas, a julgar pelo Plano Trienal, contentavam-se em ver suas idéias compondo a parte analítica dos programas de estabilização, retrocedendo imediatamente em favor da ortodoxia monetarista quando se tratava da formulação de políticas. Não era à toa que corria, na época, o irônico chiste, segundo o qual "um monetarista é um estruturalista no poder".

O Plano, de fato, reduzira-se a um plano de estabilização. E é precisamente essa a chave para compreendermos a lógica política das reações de diferentes atores ao Plano Trienal. Não foi qualquer tentativa de implementar políticas desenvolvimentistas, nem tampouco qualquer esforço para a realização das reformas de base os fatores que selaram seu destino. Tais dimensões do Plano Trienal ficaram, na prática, esquecidas, com a estratégia de estabilização consumindo todas as energias dos gestores da política econômica.

No primeiro semestre de 1963, os ministros da área econômica - Celso Furtado, no Planejamento, e San Tiago Dantas, na Fazenda - trabalharam em sintonia e com determinação para pôr em prática o Plano Trienal. Ao fim do semestre, porém, o Plano estava completamente abandonado.

Inicialmente se observou um conjunto de ataques provenientes de setores polarizados do espectro político e ideológico. De um lado, os setores nacionalistas radicais; de outro, os setores conservadores de direita. Para os primeiros, o Plano não era suficientemente nacionalista, fazendo concessões indevidas ao "imperialismo" e ao capital estrangeiro. Intelectuais ligados ao ISEB - Instituto Superior de Estudos Brasileiros, órgão de elaboração ideológica nacionalista -, por exemplo, chegaram a considerar o Plano como "solução típica" na "estratégia imperialista" de vincular o financiamento da expansão industrial brasileira à "assimilação de capital estrangeiro em ritmo mais acentuado do que o observado até aqui" (SANTOS, 1963, p. 66). Repugnava aos setores nacionalistas as negociações realizadas por San Tiago Dantas e Celso Furtado junto ao Governo norte-americano. A “missão Dantas", realizada em março de 1963, em Washington, tendo como objetivo a renegociação da dívida externa e a obtenção de empréstimos emergenciais para o país, foi a gota d'água para as forças nacionalistas. As condições impostas pelo Governo norte- americano, tais como a revisão dos processos de encampações de empresas estrangeiras concessionárias do serviço público e a condução de uma política de estabilização austera, foram tomadas como uma afronta à "política externa independente" que orientava o Governo brasileiro nas relações internacionais desde 1961.

Os setores conservadores de direita, por seu turno, consideravam o Plano excessivamente nacionalista, estatista e mesmo socialista. Carlos Lacerda, liderança máxima da oposição a Goulart, fornece-nos um exemplo do teor dessas reações: "O Sr. Celso Furtado ainda confunde o enriquecimento do povo com o enriquecimento do Estado e pensa que Governo cria riqueza. E parece considerar possível improvisar, em pouco mais de um mês, um plano para três anos, sem a contraprova decisiva da vivência dos problemas. Nós queremos planejar para construir a liberdade, os autores do Plano Trienal querem planejar para destruí-la" (CORREIO DA MANHÃ, 04/01/ 1963). Argumento idêntico encontra-se em artigo do economista Eugênio Gudin, um dos principais opositores, na área "técnica", do Plano Trienal: "Se o Sr. Celso Furtado quer, de fato, como parece, preparar a revolução totalitária da esquerda, através da pré-revolução em marcha, ao menos procure fazê-lo sem agredir os princípios mais comezinhos da análise econômica" (O GLOBO, 28/11/1962).

Essas reações iniciais pautadas por princípios ideológicos são seguidas pelas reações provenientes dos setores diretamente afetados pelas políticas restritivas da estratégia de estabilização do Plano Trienal.

A tentativa de implementação das políticas restritivas ocasionou forte mobilização contrária, tanto de setores da classe trabalhadora, quanto de importantes setores empresariais. A política salarial, por um lado, e a política de crédito, por outro, foram os fatores geradores deste tipo de reação ao Plano Trienal. Examinemos mais detidamente como se processaram essas reações decisivas para o abandono do Plano.

Com relação à política salarial, uma das principiais medidas previstas na estratégia de estabilização foi o estabelecimento de um teto de apenas $40 \%$ para o reajuste dos salários dos funcionários públicos civis e militares. Para a viabilização dessa política salarial, o Governo pretendia contar com uma atitude de colaboração das organizações sin- 
dicais. Para realizar a difícil missão de conquistar a aquiescência dessas organizações, o Presidente Goulart viu-se compelido a nomear, para o Ministério do Trabalho (cargo pelo qual ele mesmo projetara-se nacionalmente), uma liderança petebista em ascensão e com grande prestígio junto a importantes organizações dos trabalhadores como o CGT (Comando Geral dos Trabalhadores) e o PUA (Pacto de Unidade e Ação). O Deputado Almino Afonso pertencia a uma ala radicalizada do PTB, conhecida como o "Grupo Compacto", que pretendia superar a orientação pragmática e "ministerialista", representada, no partido, pela liderança de Goulart.

Num primeiro momento de sua gestão, Almino Afonso comprometeu-se com uma ação sintonizada com as políticas do Plano Trienal, embora, cautelosamente, não tenha assumido de modo muito enfático essa posição de apoio ao Plano. De qualquer modo, seu apoio pode ser depreendido dos pronunciamentos do novo Ministro imediatamente após sua posse, que ocorreu em um momento em que os trabalhadores de transportes marítimos estavam em greve há mais de um mês e havia ameaças de greves em setores importantes como os de energia elétrica, telefones e transportes urbanos. Almino Afonso solicitou um crédito de confiança aos trabalhadores, convidando-os a reavaliarem o ímpeto grevista diante da difícil situação nacional. Tal atitude foi interpretada por Prestes, líder máximo do PCB, como um pedido aos trabalhadores para que abandonassem seu direito de greve. Na verdade, como salientou Erickson, "o jovem ministro prometeu aos trabalhadores que não tinha intenções de congelar salários ou reprimir greves, mas defendeu o ponto de vista de que as reivindicações salariais não resolveriam os problemas da classe trabalhadora enquanto a economia estivesse enfraquecida. A seguir solicitou aos trabalhadores que vissem seus interesses de classe da perspectiva do interesse nacional. Operando dentro das limitações financeiras do momento, procurou, a princípio, servir aos trabalhadores eliminando a corrupção e desenvolvendo a eficiência das organizações ministeriais e previdenciárias mais próximas deles" (ERICKSON, 1979, p. 120).

Mas o fato é que essa posição de Almino Afonso tornava-se progressivamente desgastante para sua liderança política, começando a pôr em risco seu prestígio junto às esquerdas e ao movimento sindical. Desde o final de janeiro de 1963, esses setores vinham realizando manifestações contra a política econômico-financeira do Plano Trienal. A primeira investida desses setores contra o Plano foi feita pelo Partido Comunista, através de Prestes. Logo em seguida, no início de fevereiro, foi a vez do CGT posicionar-se. A mais influente organização sindical daquele período entregou um documento ao Presidente, no qual fez duros ataques ao Plano e à sua política salarial. O documento afirmava que "os novos níveis de salário mínimo já estão absorvidos pela especulação, estimulada, entre outras coisas, pela supressão dos subsídios do trigo e dos combustíveis [...]. Os trabalhadores não podem concordar com a política financeira que impõem maiores sacrifícios às massas consumidoras e deixa intactos lucros fabulosos ao capital estrangeiro, vultosas subvenções aos latifundiários e plantadores de café". Declararam-se, ainda, solidários aos funcionários públicos civis e militares "que lutam por uma elevação dos vencimentos em proporção com a alta do custo de vida". E finalizaram afirmando que "o ministério organizado pelo presidente João Goulart não pode inspirar confiança aos trabalhadores e ao povo. Expressa ainda uma política de conciliação com as cúpulas partidárias ligadas a interesses antinacionais e antipopulares" (CORREIO DA MANHÃ, 06/02/1963).

Vale lembrar que o teto de $40 \%$ para o reajuste dos salários dos funcionários soava realmente como uma discriminação, pois o salário mínimo já havia sido reajustado no final de 1962 e muitas empresas privadas estavam concedendo reajustes muito acima desse índice. Assim, os funcionários públicos iniciaram as mobilizações para que não se cumprissem as determinações do Plano Trienal neste particular. Já em meados de fevereiro, o Presidente da Federação Nacional dos Servidores Públicos declarou que "não tem cabimento que assistamos a concessão de aumento a empresas privadas em bases superiores a 70\%, em acordo salariais patrocinados pelos órgãos do Governo, com vigência a partir de janeiro, e nos curvemos a aceitar os irrisórios $40 \%$ referidos pelos poderes públicos" (CORREIO DA MANHÃ, 20/02/1963).

Entretanto, foi a partir de meados de abril que a questão salarial tornou-se mais explosiva e um obstáculo intransponível à execução do Plano Trienal. Até então as reações mantinham-se dentro de limites controláveis pelo Governo. Como assinala SOLA: "Aware of the unpopularity of the measures, Goulart had sought early March to make 
personal contact with leaders of civil servants, representative of the military and party political figures. At this stage prospects for a negotiated settlement looked good, particularly as the military were satisfied with the promise of better treatment for lower-ranking officers. The impression was confirmed by the statements of the Heads of the Civil and Military Households in favour of the Plan, and against the various pressures being brought to bear on them" (SOLA, 1982, p. 360).

Foi em meados de abril que Goulart enviou ao Congresso o projeto de aumento salarial para o funcionalismo público. Porém, conforme observou Sola, quando da apresentação do projeto, Goulart cometeu dois erros táticos que iriam comprometer definitivamente a estratégia de contenção orçamentária prevista no Plano Trienal. O primeiro deles foi não ter renovado seus contatos com as lideranças dos funcionários, tanto dos civis quanto dos militares, apesar dos preços continuarem subindo além das expectativas do Plano Trienal. Mas foi o segundo erro, relacionado com o próprio teor do projeto, que complicou ainda mais a implementação da proposta. Além da fixação do teto de $40 \%$ para os reajustes, o projeto continha uma série de medidas destinadas à distribuição de renda dentro da categoria do funcionalismo público. Assim, embora o aumento proposto para os salários básicos fosse limitado a $40 \%$, as variações iriam de $40 \%$ a $56 \%$ para os civis e de $25 \%$ a $55 \%$ para os militares (cf. SKIDMORE, 1979, p. 296). A intenção do Governo era diminuir a distância entre os maiores e os menores salários no conjunto do funcionalismo, cuja razão era de 18 por 1 . A proposta feria poderosos interesses encastelados na administração pública e, sobretudo, os interesses da alta oficialidade militar, que teria seus proventos relativamente diminuídos em favor dos escalões mais baixos da corporação.

A proposta do Governo acabou gerando uma reação conjunta dos mais diversos setores. Enfileiraram-se contra o projeto inúmeras organizações com múltiplos canais de acesso ao sistema político. No Congresso, o movimento dos funcionários obteve o apoio do PTB e da Frente Parlamentar Nacionalista, conseguindo, além disso, a adesão do PSD e da UDN, formando assim uma coalizão extremamente rara naquela conjuntura. $\mathrm{O}$ movimento contava também com o apoio de associações profissionais como a Associação de Sargentos e Marinheiros, a Associação de Oficiais e a Associação dos Funcionários
Públicos (coordenada pela Confederação Nacional dos Servidores).

O golpe de misericórdia na política salarial do Plano Trienal foi desferido pelo Ministro Almino Afonso, quando este abandonou sua posição inicial de apoio discreto ao Plano e passou a atacálo publicamente. Sua mudança de posição esteve relacionada à realização da "Missão Dantas" nos EUA, episódio que incrementou as reações dos setores nacionalistas ao Plano Trienal (cf. PARKER, 1977). O Ministro do Trabalho despontava como uma liderança emergente dentro do PTB e, ademais, desfrutava de grande prestígio junto ao movimento sindical, fato que ameaçava duplamente a liderança de Goulart. A crise que então se abriu nas relações entre o Ministro do Trabalho e o Presidente da República só se encerrou quando, em junho de 1963, Goulart dissolveu seu primeiro ministério presidencialista, sepultando também as possibilidades de implementação do Plano Trienal.

Se a política salarial do Plano Trienal foi suficiente para colocar em movimento uma série de reações ao Plano provenientes do front trabalhista e dos setores nacionalistas, um outro conjunto de políticas restritivas seria o motivo para reações advindas das elites empresariais.

No campo das organizações empresariais mais influentes do período podia-se distinguir dois tipos de atitudes iniciais com relação ao Plano Trienal. Para organizações empresariais como a Associação Comercial do Rio de Janeiro, a Associação Comercial de São Paulo e a Federação das Indústrias da Guanabara, o Plano constituía-se como ameaça à "liberdade econômica", tendo em vista suas tendências "estatistas" e supostamente "socializantes". Eram reações de combate imediato ao Plano embaladas por uma argumentação solidamente amparada nos princípios doutrinários do liberalismo econômico.

Porém, o mais interessante, a nosso ver, é observar o comportamento dos setores empresariais que manifestaram inicialmente uma posição de apoio ao Plano Trienal e as razões pelas quais, em seguida, retiraram tal apoio. As mais influentes organizações empresariais a emprestarem apoio imediato ao Plano eram provenientes do setor industrial, como a Confederação Nacional da Indústria (CNI), a Federação das Indústrias do Estado de São Paulo (FIESP) e a Federação das Indústrias do Rio Grande do Sul (FIRGS). 
Em sua parte relativa às políticas monetária $\mathrm{e}$ de crédito, o Plano Trienal garantia que, apesar da austeridade prevista no tratamento da expansão monetária, "o crédito ao setor privado deverá crescer em montante correspondente à elevação do nível de preços adicionado ao aumento do produto real" (PLANO TRIENAL, 1963, p. 10). Devido a essa ressalva, as elites industriais saudaram o Plano como uma real alternativa às tradicionais políticas de estabilização de caráter ortodoxo.

Em fevereiro de 1962, a revista técnica da CNI afirmava que o Plano Trienal teria todas as condições para tornar-se uma força dominante na evolução econômica do país. Louvava-se, particularmente, o fato de que "a política de crédito garante que o setor privado não sofrerá pressões que forcem a retração dos investimentos" (DESENVOLVIMENTO E CONJUNTURA, fev.1963, p. 12). Logo em seguida, no início de março, a CNI enviou um memorandum a Goulart, no qual garantia que iria tomar uma série de medidas de apoio ao Plano Trienal. A elite industrial comprometia-se a persuadir os membros de sua base para que não praticassem aumentos de preços acima dos aumentos dos custos, não formassem estoques especulativos e para que trabalhassem com vistas a aumentar a produtividade, em colaboração com os trabalhadores.

Havia, porém, no referido memorandum, uma outra preocupação dos empresários transmitida ao Presidente. Tal preocupação soava, na verdade, como condição do apoio dos industriais ao Plano e se relacionava à questão salarial.

Já em fevereiro, no mesmo número em que saldava o Plano, a revista da CNI dizia que o Plano Trienal falhava em não prever as linhas de uma política salarial abrangente, resumindo-se, neste ponto, à fixação de um teto de $40 \%$ para o aumento dos funcionários públicos. Consideravam equivocada a concepção de Furtado de que a redução das diferenças salariais e a dificuldade de acabar com os salários privilegiados seriam os principais problemas neste campo. Argumentavam que tal abordagem, ao destruir a escala salarial, era contraditória com o objetivo de aumentar a produtividade, pois retiraria os estímulos à especialização e à aquisição de conhecimento técnico. Os industriais preocupavam-se, ainda, com uma possível orientação política na questão salarial, decorrente de uma presumível inaptidão do Governo para lidar com "pressões demagógicas"

\section{(cf. FIGUEIREDO, 1987, p. 117).}

Observe-se que o apoio ao Plano por parte das elites industriais não era uma adesão incondicional. Tampouco o fizeram por colocar supostos interesses nacionais acima dos seus próprios. $\mathrm{O}$ apoio foi emprestado sob a dupla condição de que não lhe faltasse crédito e que fosse contida a escalada reivindicatória dos trabalhadores. A evidência disso é que, a partir do segundo trimestre de 1963, a posição desse setor empresarial mudou do apoio à crítica, quando os empresários passaram a sentir os efeitos do aperto de liquidez ocasionado pela restrição do crédito e, além disso, constataram que o Governo não dispunha de meios para conter as reivindicações salariais, como ficou explícito no caso dos funcionários públicos.

O impacto das medidas antiinflacionárias do Plano Trienal só seria plenamente sentido no segundo semestre. Mas a deterioração das condições econômicas e as medidas tomadas pelo Governo ao longo do primeiro semestre de execução já configuravam o cenário para a retirada gradativa do apoio dos setores empresariais. $\mathrm{Na}$ verdade, os indicadores do primeiro trimestre de 1963 já apontavam para o fracasso do Plano Trienal. "Em janeiro de 1963 houve um aumento do salário mínimo de 56,25\%. Em fevereiro, as tarifas de transportes urbanos foram corrigidas entre 22 e $29 \%$. Em março eliminou-se o subsídio ao trigo importado, o que elevou seu preço em $100 \%$, e ao petróleo importado, o que elevou seu preço doméstico em $70 \%$. Em abril, o cruzeiro foi desvalorizado em $30,4 \%$. O resultado dessas e outras medidas do processo de 'inflação corretiva', tomadas no primeiro trimestre de 1963, repercutiu imediatamente na taxa de inflação [...]. Simultaneamente o Governo embarcava numa política de limitação da expansão do crédito. Através das instruções 234 e 235, o crescimento dos empréstimos ao setor privado, tanto do Banco do Brasil como dos bancos comerciais, foi limitado em $35 \%$ em termos nominais, durante o ano, enquanto a taxa de inflação do primeiro trimestre ficava em torno de $60 \%$ em termos anuais. O compulsório dos bancos comerciais foi elevado de 24 para $28 \%$, completando o pacote de medidas restritivas na área monetária" (RESENDE, 1982, p. 763).

Ante a nova conjuntura que emergia no segundo trimestre de 1963, a CNI, em abril intensificou sua crítica à ausência de uma política salarial definida e passou a reivindicar mais 
flexibilidade do Governo na liberação de crédito ao setor privado. No mesmo documento em que reivindicava aumento de crédito, a CNI sugeria uma política global de redução do salário real: "Nós obviamente não esperaríamos que o Ministro da Fazenda fizesse uma declaração pública de que pretende relaxar os limites de crédito no Plano. Isso seria um erro pois ameaçaria o clima psicológico de contenção de preços que tem sido tão duramente conseguido [...]. Ele poderia porém elevar os tetos para prover com maiores facilidades de crédito os setores que tenham provado ser mais sensíveis às políticas restritivas". E em seguida ataca a questão salarial: "as medidas requeridas pela contenção de preços com desenvolvimento teriam mais chances de sucesso se fossem estendidas para todas as categorias de assalariados e não somente aos funcionários públicos. Assim, o reajuste de salários deveria ser feito ao nível de $10 \%$ abaixo do incremento do custo de vida" (DESENVOLVIMENTO E CONJUNTURA, abril.1963, p. 3-4).

A posição dos empresários industriais com relação à questão salarial vai se tornando, cada vez mais, politicamente orientada, criando mais um obstáculo às veleidades conciliatórias do Plano Trienal. A reação dos empresários refletia a movimentação dos trabalhadores via CGT. A FIESP temia e passou a denunciar os planos de uma greve geral que teria o objetivo de solapar a autoridade do Governo e levar à bancarrota o Plano Trienal. Tanto a FIESP quanto a CNI condenaram violentamente, por exemplo, a escalada das demandas dos trabalhadores de transportes por melhores salários. Essa categoria de assalariados constituíase na coluna dorsal das greves gerais ocorridas em 1962, fato que reforçava os temores dos empresários. A poderosa FIESP afirmava em seu Boletim informativo, do mês de maio, que as demandas dos trabalhadores de transportes por maiores salários ultrapassava "os limites do inconcebível, da ignomínia e da absoluta insensibilidade para com o interesse nacional [...] constituem-se numa autêntica gangue [...] sugando o sangue da nação em vantagem própria" (apud FIGUEIREDO, 1987, p. 120).

Assim, o Plano Trienal perdeu sua mais influente base de apoio entre os grupos sócio-econômicos. Após uma fase de apoio condicional durante o primeiro trimestre de 1963, a elite industrial passou a fazer oposição ao Plano, em razão de o Governo não ter obtido as condições estabelecidas como contrapartida ao apoio: nem o crédito acessível à indústria foi garantido, nem o movimento sindical foi controlado pelo Governo. Foi o fim do Plano Trienal e o começo do fim do Governo Goulart.

\section{CONSIDERAÇÕES FINAIS}

$\mathrm{O}$ exame das experiências de planejamento econômico ocorridas entre o final do anos cinqüenta e o golpe militar de 1964 revelou uma profunda inflexão em relação à estratégia da política econômica adotada durante os anos de auge do desenvolvimentismo. É possível afirmar que um novo consenso ideológico estava se formando entre os principais atores responsáveis pela formulação e implementação da política econômica oficial. A meta da estabilidade monetária sobrepunha-se à meta do desenvolvimento industrial do país, apresentada, até então, como verdadeira panacéia para a superação do subdesenvolvimento e da desigualdade, sobretudo durante os anos cinqüenta, nos Governos de Vargas e de Kubitschek. Embora o país tenha apresentado um impressionante salto no processo de industrialização, em grande medida devido à bem sucedida implementação do Plano de Metas, o subdesenvolvimento $\mathrm{e}$ as desigualdades sociais e regionais persistiam. Além disso, novos problemas surgiam, como a aceleração do processo inflacionário e a deterioração das contas externas, problemas em parte decorrentes da própria estratégia desenvolvimentista de Kubitschek.

O esgotamento da força aglutinadora da ideologia desenvolvimentista, expressão do malogro da promessa da industrialização como panacéia, cedeu lugar a idéias e movimentos políticos das mais variadas tendências. À esquerda fortaleciase o movimento pela realização das reformas de base de caráter distributivista e nacionalista, enquanto à direita crescia o apelo à recomposição da ordem econômica (fim da inflação) e da ordem política (contenção das mobilizações sociais). No que se refere à evolução da política econômica, o que se observa é a crescente aceitação, pelos governantes e tecnocratas, da idéia de que o combate à inflação deveria ser prioritário e precedente a qualquer outro objetivo político-econômico. Isso fica evidente não somente nos experimentos do PEM do Governo Kubitschek e da Reforma Cambial do Governo Quadros, mas também, embora de modo menos evidente, no Plano Trienal do Governo Goulart. 
O malogro das tentativas de planejamento da economia, naquele momento de crise, deve ser explicado pelas reações dos atores políticos e dos agentes econômicos aos efeitos adversos provocados pelas políticas de estabilização. É verdade que o clima de radicalização e polarização ideológica da época impunha sérias restrições à aceitação das medidas contidas nos diferentes experimentos de estabilização. O Plano Trienal, por exemplo, tanto foi acusado de pró-imperialista e "entreguista", quanto de pró-comunista. Mas o fato é que não havia nenhum motivo, ao menos no horizonte de curto prazo imposto pela crise, para que os principais grupos sócio-econômicos se resignassem aos "sacrifícios" que as políticas ortodoxas de estabilização impunham.

$\mathrm{Na}$ conjuntura do início dos anos sessenta, romperam-se irreversivelmente as alianças sóciopolíticas que vinham dando sustentação à estratégia político-econômica desenvolvimentista. As mobilizações crescentes dos setores organizados das classes populares pelas reformas de base encerravam um longo ciclo de ação tutelada pelo Estado populista. Trabalhadores urbanos e camponeses afirmavam sua autonomia frente às decisões das elites estatais e passavam a vocalizar demandas cujo atendimento implicaria uma profunda redistribuição de riqueza e de poder entre as classes sociais e, conseqüentemente, a realização de um novo pacto de poder. Aos setores populares já não era mais convincente o argumento de que seus problemas seriam resolvidos com a industrialização do país. Qualquer medida que representasse protelação na realização das reformas de base era interpretada como expressão do desejo de setores conservadores.

Na contramão das demandas dos trabalhadores realizaram-se os ensaios de política econômica do período. Aquilo que as elites técnicas interpre- tavam como "necessidade econômica", ou seja, a concentração imediata de esforços para o controle da inflação, apresentava-se como incompatível com a realização das reformas de base. $E$ isso porque a maior parte das terapias antiinflacionárias, cristalizadas nos programas de estabilização, permanecia nos quadros de referência de uma ideologia econômica ortodoxa, que associava a busca da estabilidade econômica com a imposição de sacrifícios ao consumo. Contenção de reajustes salariais, limitação do crédito ao consumidor, eliminação de subsídios ao consumo, corte nos gastos públicos etc. passavam a constituir o eixo dos programas de estabilização.

A tônica antiinflacionária e o desdém às reformas distributivistas estiveram presentes até mesmo no Plano Trienal do Governo Goulart. Mesmo tendo ficado sob o comando de Celso Furtado, principal expressão do pensamento reformista da Cepal, o Plano Trienal não escapou aos imperativos da "necessidade econômica" do momento. Elegeu a inflação como o problema mais grave e imediato a ser tratado, relegando o planejamento das reformas a um futuro sem data prevista. Mais uma vez, o que as elites estatais pediam ao povo era o sacrifício do presente para o suposto regozijo do futuro. Mas esse era um argumento político pouco convincente no quadro da crise. O Plano Trienal não obteve o apoio dos trabalhadores e o Governo Goulart não conquistou a confiança das classes dominantes, que esperavam a contenção da inflação e o controle governamental das greves e das mobilizações sociais. A frustração da tentativa de conciliação de classes, presente no Plano Trienal, agravou o isolamento do Governo Goulart e, de alguma maneira, contribuiu para o trágico desfecho da crise em março de 1964.

Recebido para publicação em 12 de setembro de 1999.

Ricardo Silva (rsilva@cfh.ufsc.br) é Mestre em Ciência Política na Universidade Estadual de Campinas (UNICAMP), Doutor em Ciências Sociais pela mesma universidade e Professor do Departamento de Sociologia e Ciência Política na Universidade Federal de Santa Catarina (UFSC).

\section{REFERÊNCIAS BIBLIOGRÁFICAS}

AFONSO, A. 1988. Raizes do golpe. Da crise da legalidade ao Parlamentarismo (1961-1963). São Paulo: Marco Zero.
BANDEIRA, M. 1979. A renúncia de Quadros e a crise pré-64. $2^{\mathrm{a}}$ ed. São Paulo: Brasiliense.

BAER, W. 1962. Observações sobre o Plano 
Trienal. Revista Brasileira de Economia, ano XVI, n. 4.

1985. A industrialização e o desenvolvimento econômico no Brasil. $6^{\mathrm{a}}$ ed. Rio de Janeiro: Fundação Getúlio Vargas.

BENEVIDES, M. V. 1976. O Governo Kubitschek : desenvolvimento econômico e estabilidade política 1956-1961. 2a ed. Rio de Janeiro: Paz e Terra.

BIELSCHOWSKI, R. 1988. O pensamento econômico brasileiro: o ciclo ideológico do desenvolvimentismo. Rio de Janeiro: IPEA/ PNPE.

BRASIL. PRESIDÊNCIA DA REPÚBLICA. Ministério Extraordinário do Planejamento. Plano trienal de desenvolvimento econômico e social-1963-1965. Brasília: Síntese.

CASTELLO BRANCO, C. 1975. Introdução à Revolução de 1964: a agonia do poder civil. Rio de Janeiro: Arte Nova.

CRUZ, P. D. 1980. Ignácio Rangel, um pioneiro. O debate econômico no início dos anos sessenta. Campinas. Dissertação (Mestrado em Economia). Universidade Estadual de Campinas.

ERICKSON, K. 1979. O sindicalismo no processo político no Brasil. São Paulo: Brasiliense.

FIGUEIREDO, A. C. 1987. Political Coalitions in Brazil, 1961-1964: democratic alternatives to the political crisis. Chicago. Tese (Doutorado em Ciência Política). University of Chicago.

FIGUEIREDO, A. C. 1993. Democracia ou reformas: alternativas democráticas à crise política, 1961-1964. Rio de Janeiro: Paz e Terra.

FURTADO, C. 1989. A fantasia desfeita. $3^{\mathrm{a}} \mathrm{ed}$. Rio de Janeiro: Paz e Terra.

GUDIN, E. 1965. Análise de problemas brasileiros. Rio de Janeiro: Agir.

HIRSCHMAN, A. (org.). 1967. Monetarismo $x$ Estruturalismo. Rio de Janeiro: Lidador.

IANNI, O. 1986. Estado e planejamento econômico no Brasil. $4^{\mathrm{a}}$ ed. Rio de Janeiro: Civilização Brasileira.
LAFER, C. 1975. O Plano de Metas. In: LAFER, B. M. O planejamento no Brasil. São Paulo: Perspectiva.

LESSA, C. 1982. Quinze anos de política econômica. São Paulo: Brasiliense.

MARTINS, L. 1962. Temas de hoje. Rio de Janeiro: Editora da União Nacional dos Estudantes.

1976. Pouvoir et développment économique: formation et évolution des structures politiques au Brésil. Paris: Anthropos.

PARKER, P. 1977. 1964: o papel dos Estados Unidos no golpe de Estado de 31 de março. 2a ed. Rio de Janeiro: Civilização Brasileira.

RESENDE, A. L. 1982. A política brasileira de estabilização: 1963-1968. Pesquisa e Planejamento Econômico, v. 12, n. 3, dez.

SANTOS, W. G. 1963. Reforma contra reforma. Rio de Janeiro: Tempo Brasileiro.

SILVA, R. V. 1992. Política e política econômica na crise do início dos anos sessenta. O Plano Trienal de Desenvolvimento Econômico e Social (1963-1965). Campinas. 210 p. Dissertação (Mestrado em Ciência Política). Universidade Estadual de Campinas.

SKIDMORE, T. 1979. Brasil: de Getúlio a Castelo. $6^{\text {a }}$ ed. Rio de Janeiro: Paz e Terra.

SOCHACZEWSKI. A. C. 1980. Financial and economic development of Brazil, 1945-1963. Londres. Tese (Doutorado em Economia). London School of Economics and Political Science.

SOLA, L. 1982. The political and ideological constraints to economic management in Brazil, 1945-1963. Somerville. 397 p. Tese (Doutorado em Ciência Política). University of Oxford.

1998. Idéias econômicas, decisões políticas. São Paulo: Edusp.

VICTOR, M. 1965. Cinco anos que abalaram o Brasil. Rio de Janeiro: Civilização Brasileira.

WELLS, J. 1977. Growth and fluctuations in the Brazilian manufacturing sector during the 1960's and early 1970's. PhD Thesis, Cambridge: Cambridge University. 


\section{OUTRAS FONTES}

Correio da Manhã. 14.mar.1961; 15.mar.1961; 4.jan.1963; 6.fev.1963; 20.fev.1963.
Desenvolvimento e Conjuntura. Fev.1963; Abr.1963.

O Globo. 28.nov.1962. 